\title{
Feedback between erosion and active deformation: geomorphic constraints from the frontal Jura fold-and-thrust belt (eastern France)
}

\author{
Herfried Madritsch • Olivier Fabbri · \\ Eva-Marie Hagedorn · Frank Preusser • \\ Stefan M. Schmid · Peter A. Ziegler
}

Received: 28 September 2008/ Accepted: 12 July 2009/Published online: 2 August 2009

(C) Springer-Verlag 2009

\begin{abstract}
A regional tectono-geomorphic analysis indicates a Pliocene to recent rock uplift of the outermost segment of the Jura fold-and-thrust belt, which spatially coincides with the intra-continental Rhine-Bresse Transfer Zone. Elevated remnants of the partly eroded Middle Pliocene Sundgau-Forêt de Chaux Gravels identified by heavy mineral analyses allow for a paleo-topographic reconstruction that yields minimum regional Latest Pliocene to recent rock uplift rates of $0.05 \pm 0.02 \mathrm{~mm} /$ year. This uplift also affected the Pleistocene evolution of the Ognon and Doubs drainage basins and is interpreted as being tectonically controlled. While the Ognon River was deflected from the uplifted region the Doubs deeply incised into it.
\end{abstract}

H. Madritsch $(\bowtie) \cdot$ S. M. Schmid · P. A. Ziegler

Geological-Paleontological Institute,

Universität Basel, 4056 Basel, Switzerland

e-mail: herfried.madritsch@nagra.ch

Present Address:

H. Madritsch

Nagra, Hardstrasse 73, 5430 Wettingen, Switzerland

O. Fabbri

UMR 6249 Chrono-Environnement, Université de

Franche-Comté, 25030 Besançon cedex, France

E.-M. Hagedorn

51381 Leverkusen, Germany

F. Preusser

Institute of Geological Sciences,

Universität Bern, 3012 Bern, Switzerland

Present Address:

S. M. Schmid

Institut für Geologische Wissenschaften, FU Berlin,

12249 Berlin, Germany
Focused incision of the Doubs possibly sustained ongoing deformation along anticlines which were initiated during the Neogene evolution of the thin-skinned Jura fold-and-thrust belt. At present, this erosion-related active deformation is taking place synchronously with thick-skinned tectonics, controlling the inversion of the Rhine-Bresse Transfer Zone. This suggests local decoupling between seismogenic basement faulting and erosion-related deformation of the Mesozoic cover sequences.

Keywords Rock uplift - Incision - Alluvial terraces · Active folding · Jura fold-and-thrust belt

\section{Introduction and objectives of this study}

Intracontinental active deformation is often characterised by low seismicity and very slow horizontal and vertical displacement rates. Under such conditions, seismological and geodetic surveys often fail to decipher neotectonic deformations. Instead, landscape evolution studies, especially those considering geomorphic markers that are capable to record slow and eventually aseismic deformation over long time scales have proved to be an effective tool in neotectonic research (Ouchi 1985; Merritts et al. 1994; Holbrook and Schumm 1999).

The Franche-Comté region of eastern France straddles the boundary between the northwestern deformation front of the Alpine orogen and its foreland. Here the Neogene Jura fold-and-thrust belt encroached onto the Eo-Oligocene fault system of the Rhine-Bresse Transfer Zone, a segment of the European Cenozoic Rift System (Laubscher 1970; Contini and Théobald 1974; Lacombe et al. 1993; Martin and Mercier 1996; Madritsch et al. 2009; Figs. 1, 2). At present, this area is characterised by low to intermediate 


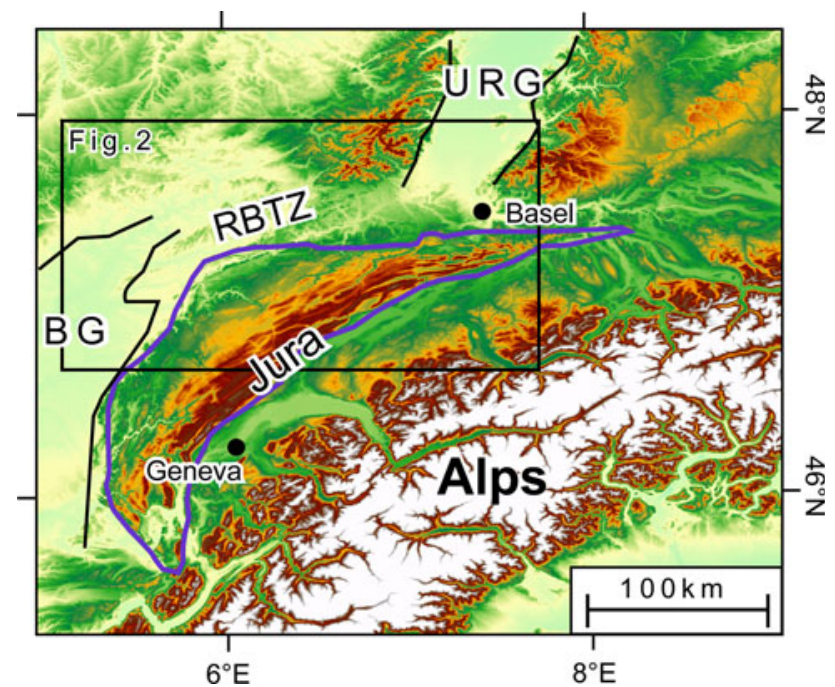

Fig. 1 Digital elevation model of western central Europe (SRTM data) showing the location of the study area (Fig. 2) seismicity that is significantly lower than in the adjacent southern parts of the Upper Rhine Graben (Baer et al. 2007; RéNaSS 2007; Fig. 2). Consequently, the present-day stress field of the Franche-Comté region is poorly defined (Kastrup et al. 2004). Nevertheless, the area is prone to seismic hazard as evidenced by the $\mathrm{M}_{\mathrm{L}} 4.8$ Rigney earthquake of 23 February 2004 (Baer et al. 2005), one of the strongest recent seismic events in the wider area. Moreover, the famous 1356 Basel earthquake, which represents one of the strongest historically recorded seismic events throughout central Western Europe (Mayer-Rosa and Cadiot 1979), was possibly triggered by motions along an ENE-WSW striking basement fault of the Late Paleozoic Burgundy Trough System that underlies the Cenozoic Rhine-Bresse Transfer Zone (Meyer et al. 1994; Ustaszewski and Schmid 2007).

Middle- to short-term geodetic surveying indicates very slow vertical and horizontal ongoing displacement rates
Fig. 2 Tectonic setting of the study area (tectonic units modified after Madritsch et al. 2008) and epicentres with related magnitudes of instrumentally recorded earthquakes since $1980\left(\mathrm{M}_{\mathrm{L}}>3\right.$ source: RéNaSS 2007). The focal mechanism of the Rigney earthquake is based on full waveform moment tensor inversion by Baer et al. (2005). Also shown is the extent of the Late-Paleozoic Burgundy Trough System in the subsurface of the RBTZ (lower right). AJ Ajoie area, $A M F$ Avant-Monts Fault, $A M Z$ Avant-Monts Zone, $B G$ Bresse Graben, $B Z$ Besançon Zone, $\mathrm{CH}$ Chailluz Thrust, $F B$ Faisceau Bisontin, LSH La Serre Horst, $M P$ Montbéliard Plateau, RBTZ Rhine-Bresse Transfer Zone, URG Upper Rhine Graben

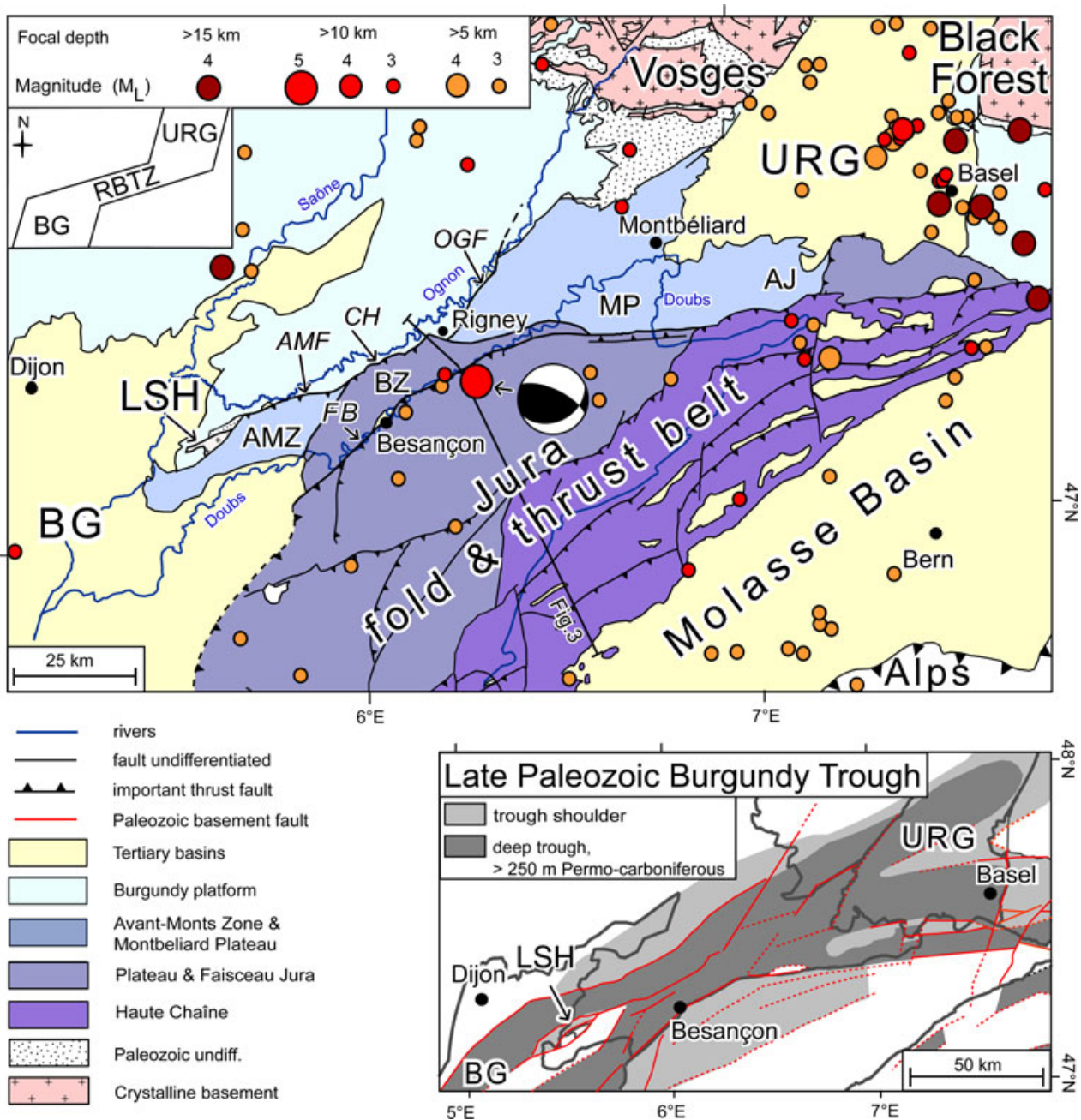


throughout the northwestern Alpine foreland, close to the margin of error inherent to current GPS technology (Tesauro et al. 2005). Despite this, there are indications for recent deformation within the area provided by pioneering studies in tectonic geomorphology (Dreyfuss and Glangeaud 1950; Liniger 1967; Théobald et al. 1977; Campy 1984). More recent studies applying modern techniques based on digital elevation models are so far restricted to areas in the southern and northern parts of the Upper Rhine Graben area (Nivière and Marquis 2000; Giamboni et al. 2004b; Peters and van Balen 2007), but are still lacking in the Rhine-Bresse Transfer Zone proper.

This study aims at a better understanding of the Pliocene to recent tectonic evolution of this region by investigating two different geomorphic markers. A first marker is provided by the paleo-topographic reconstruction of the Middle Pliocene Sundgau-Forêt de Chaux gravel surface. These gravels were deposited by a braided river that formed part of the Aare-Doubs drainage system (Liniger 1967; Bonvalot 1974; Petit et al. 1996; Ziegler and Fraefel 2009) and presumably post-date the formation of the thin-skinned Jura fold-and-thrust belt (Becker 2000; Ustaszewski and Schmid 2007). Plio-Pleistocene terraces along the valleys of the Ognon and Doubs rivers provide a second set of geomorphic markers. Our investigations build upon a new tectonic map of the area (Madritsch et al. 2008; Fig. 2), combined with a revised map of alluvial sediments based on published geological maps, our own field observations and analyses of digital elevation models. Furthermore, we implemented a regional-scale, comparative heavy mineral analysis in order to constrain the provenance of river deposits at key locations.

\section{Tectonic setting}

The study area is characterised by three major tectonic elements: (1) the Permo-Carboniferous Burgundy Trough, (2) the Eo-Oligocene Rhine-Bresse Transfer Zone (RBTZ), which is superimposed on the Burgundy Trough and forms part of the European Cenozoic Rift System (ECRIS) and (3) the Neogene Jura fold-and-thrust belt.

The roughly ENE-WSW striking Permo-Carboniferous Burgundy Trough System is oriented parallel to the RBTZ (Fig. 2). It extends over a distance of about $300 \mathrm{~km}$ from the northern parts of the Massif Central, through the Bresse Graben into the area of the RBTZ, and further to Basel where it links with the Permo-Carboniferous graben system of northern Switzerland and southern Germany (Boigk and Schönreich 1970; Debrand-Passard and Courbouleix 1984; Ziegler 1990). In the area of the RBTZ, the Burgundy Trough is buried beneath Mesozoic sediments except for the narrow La Serre Horst (Coromina and Fabbri 2004;
LSH in Fig. 2). Deep wells drilled in the area penetrated up to $800 \mathrm{~m}$ of Permo-Carboniferous sediments beneath the Mesozoic series (compare Chauve et al. 1983; Madritsch et al. 2009).

The ECRIS developed in Eocene-Oligocene times and dissects the European continent over a distance of approximately $1,100 \mathrm{~km}$ from the Dutch North Sea coast to the western Mediterranean (Ziegler 1992). The RBTZ forms an important element of this rift system and connects the Upper Rhine Graben with the Bresse Graben (Laubscher 1970; Illies 1972; Contini and Théobald 1974; Fig. 2). During the main rifting phase that started in Middle to Late Eocene times (Berger et al. 2005; Hinsken et al. 2007) the RBTZ formed by extensional to sinistral transtensional reactivation of the Permo-Carboniferous Burgundy Trough System (Lacombe et al. 1993). This reactivation also contributed to the exhumation of the $\mathrm{La}$ Serre Horst (Madritsch et al. 2009). During the Middle Miocene (Burdigalian), the southern parts of the Upper Rhine Graben and the RBTZ were uplifted together with the Vosges-Black Forest Arch. This large-scale uplift was probably controlled by lithospheric folding, reflecting the build-up of collision-related compressional stresses in the Alpine foreland (Dèzes et al. 2004).

To the southeast, the RBTZ is bordered and partially overridden, by the Neogene Folded Jura, which is considered as a textbook example of a thin-skinned foreland fold-andthrust belt (see review in Sommaruga 1997). Its development is generally considered as a relatively short-lived event spanning Late Miocene to Early Pliocene times (10.54.2 Ma according to Ustaszewski and Schmid 2006) and widely accepted as resulting from "distant push" (Laubscher 1961), induced by Late Miocene crustal shortening and nappe stacking in the external crystalline massifs of the Central Alps. Large scale thin-skinned decoupling (décollement) of the Mesozoic sedimentary cover along a sole thrust in Middle to Late Triassic evaporites permitted northwestward propagation of the thrust front towards the distal foreland (Laubscher 1972; Burkhard 1990; Schmid et al. 1996; Burkhard and Sommaruga 1998). The weakly deformed Besançon Zone (Figs. 2, 3) represents the most external segment of the thin-skinned Jura fold-and-thrust belt that encroached onto the preexisting fault systems of the RBTZ and the underlying Burgundy Trough (Madritsch et al. 2008; Figs. 2, 3). Towards the southeast, the Besançon Zone is bordered by the Faisceau Bisontin, an approximately 100-km-long closely spaced bundle of ENE-WSW striking folds and thrusts (FB in Figs. 2, 3; Chauve et al. 1980; Dreyfuss and Glangeaud 1950). The Chailluz Thrust (CH in Fig. 2), the outermost thrust of the thin-skinned fold-andthrust belt, delimits the Besançon Zone to the northwest.

Mechanisms controlling post-4.2 Ma deformation in the Folded Jura and its northern foreland are a matter of 
Fig. 3 Structural cross section through the Jura fold-and-thrust belt (modified after Sommaruga 1997), see Fig. 2 for location. $A M F$ Avant-Monts Fault, $\mathrm{CH}$ Chailluz Thrust, $F B$ Faisceau Bisontin

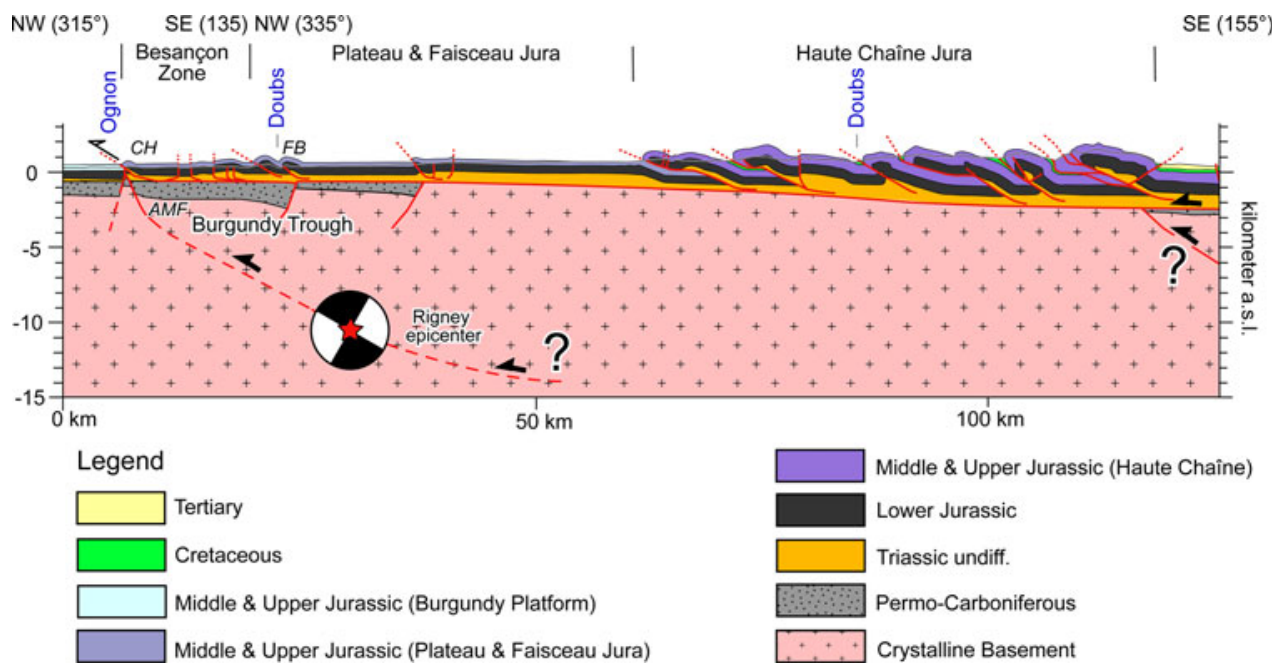

controversy. While some authors proposed that thin-skinned fold-and-thrust belt propagation continued into Pleistocene times (Nivière and Winter 2000), others infer a switch towards thick-skinned tectonics involving shortening of the crystalline basement beneath the detached Mesozoic cover sediments of the fold-and-thrust belt and in its foreland (Meyer et al. 1994; Giamboni et al. 2004a; Rotstein and Schaming 2004; Ustaszewski and Schmid 2007; Fig. 3). In the study area, thick-skinned deformation is documented by reflection-seismic data along the AvantMont Fault (AMF in Figs. 2, 3), a steeply south dipping reverse fault that is rooted in the basement and most likely formed by inversion of a former normal fault of Paleogene to Paleozoic age (Madritsch et al. 2008). On a regional scale, thick-skinned tectonics have been interpreted to involve compressional to dextral transpressional partial reactivation of the RBTZ post-dating the main stage of the thin-skinned Jura fold-and-thrust belt development (Giamboni et al. 2004a; Ustaszewski and Schmid 2007; Madritsch et al. 2008).

\section{Drainage system evolution and geomorphic setting}

The digital elevation model of Franche Comté (horizontal resolution $50 \mathrm{~m}$; Fig. 4) shows that the topographic relief of the area is closely related to tectonic structures. The main morphological and structural features of the region strike ENE-WSW. The fault-related folds along the Chailluz Thrust, the Avant-Monts Fault and along the Lomont, Bisontin and Quingey Faisceaux form distinct ridges. The modern drainage pattern of the region is roughly parallel to the ENE-WSW striking structural trend and has undergone a complex Neogene evolution that was controlled by tectonic and climatic events (Liniger 1966; Petit et al. 1996; Giamboni et al. 2004b; Berger et al. 2005; Ziegler and Fraefel 2009).
In the Late Miocene, prior to the formation of the Jura fold-and-thrust belt (10.5-4.2 Ma according to Ustaszewski and Schmid 2006), the RBTZ was characterised by a southdirected drainage system that developed in response to Burdigalian uplift and exhumation of the Vosges Mountains (Ziegler and Dèzes 2007; Ziegler and Fraefel 2009; Fig. 5a). This drainage system controlled the deposition of the Vosges-derived Bois de Raube Formation in the Ajoie area (Fig. 2) and in the north-central Jura Mountains (Kälin 1997). Remnants of fluvial deposits possibly related to this early drainage system occur only very locally in the area of the RBTZ.

The Aare-Doubs drainage system developed only after the main deformation phase of the thin-skinned Jura foldand-thrust belt (Liniger 1967; Giamboni et al. 2004a; Ziegler and Fraefel 2009; Fig. 5b). During this stage, the Paleo-Aare River, draining the Molasse Basin, flowed along the deformation front of the Jura fold-and-thrust belt westward and via the Bresse Graben into the Mediterranean Sea. As such, the course of the Paleo-Aare was parallel to the lower reach of the present-day Doubs River (Fig. 5c). It is this Middle Pliocene Aare-Doubs drainage system that controlled the deposition of the Sundgau-Forêt de Chaux (SFC) Gravels (Fig. 6a). These gravels are characterised by pebble and heavy mineral spectra of Alpine provenance (Liniger and Hofmann 1965; Bonvalot 1974; Hagedorn 2004) and have a bio-stratigraphically constrained Middle Pliocene depositional age of 4.22.9 Ma (Petit et al. 1996; Fejfar et al. 1998). Their deposition is claimed to post-date the thin-skinned deformation phase of the Jura fold-and-thrust belt (Becker 2000; Ustaszewski and Schmid 2006). The sediment load for the Paleo-Aare was provided by increased sediment discharge from the Alps and the Molasse Basin (Kuhlemann et al. 2002), both of which underwent large-scale uplift and erosion during the Pliocene (Cederbom et al. 2004). 
Fig. 4 Shaded digital elevation model (50 m horizontal resolution) of the study area showing the major faults and the drainage basins of the Doubs and Ognon River. Note that the Middle Pliocene SundgauForêt de Chaux Gravels are eroded in the study area. The red line indicates the approximate trace of the schematic cross section shown in Fig. 13. AMF Avant-Monts Fault, $A M Z$ Avant-Monts Zone, $B G$ Bresse Graben, $B Z$ Bresse Graben, $\mathrm{CH}$ Chailluz Thrust, $F B$ Faisceau Bisontin, $F L$ Faisceau du Lomont, $F Q$ Faisceau de Quingey, $L S H$ La Serre Horst, $M P$ Montbéliard Plateau, $U R G$ Upper Rhine Graben

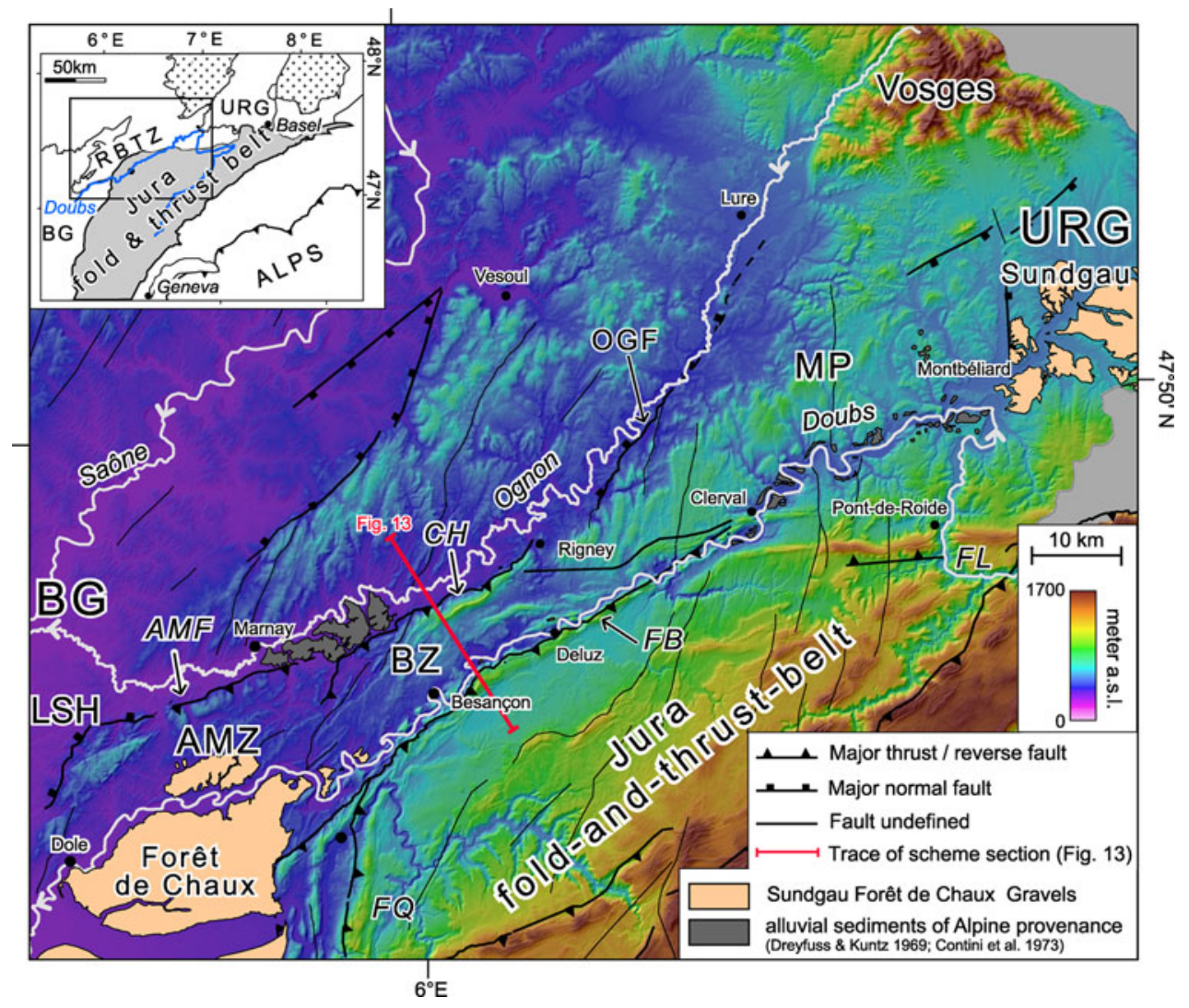

The Paleo-Aare River persisted only until the early Late Pliocene (2.9 Ma). Around that time the Paleo-Aare River was deflected near Basel into the Upper Rhine Graben, in response to subsidence of the latter and possibly also due to compressional deformation and uplift of the RBTZ (Ziegler and Dèzes 2007). With this deflection, the present-day Aare-Rhine River was established which flowed northward into the North Sea (Liniger 1966; Petit et al. 1996; Giamboni et al. 2004a; Ziegler and Fraefel 2009; Fig. 5c). Owing to this Late Pliocene drainage system reorganisation the area of the RBTZ became permanently isolated from Alpine sediment supply.

The deposits of the Middle Pliocene Paleo-Aare (4.2$2.9 \mathrm{Ma}$ ) are only well preserved in the Sundgau region at the southern end of the Upper Rhine Graben and again over $100 \mathrm{~km}$ further to the southwest in the Forêt de Chaux area adjacent to the Bresse Graben (Fig. 4). Only in these two areas do the SFC Gravels form a more or less continuous depositional surface. The gravels rest with an erosional unconformity on Mesozoic and/or Tertiary strata (Liniger 1967). In the Sundgau area the SFC gravel sheet reaches a thickness of $30 \mathrm{~m}$ (Giamboni et al. 2004b), while in the Forêt de Chaux thicknesses of up to $65 \mathrm{~m}$ are reported (Chauve et al. 1979). Sedimentological features of the SFC Gravels imply that they were deposited by a low-gradient braided river system characterised by low sinuosity shifting channels (Giamboni et al. 2004b). These observations indicate that the SFC Gravels were deposited on a broad and gently inclined peneplane and were unable to infill a paleorelief exceeding some $30-65 \mathrm{~m}$. The fact that the SFC Gravels were deposited during a closely constrained time span (4.2-2.9 Ma; Petit et al. 1996; Fejfar et al. 1998) and on a more or less flat surface $( \pm 65 \mathrm{~m})$ makes them an excellent marker horizon that permits to reconstruct the Middle Pliocene paleo-topography and that possibly records late-stage deformations (Giamboni et al. 2004a).

In the study area, located between the Sundgau and Forêt de Chaux areas, no coherent SFC gravel deposits are preserved (Fig. 4). Only isolated remnants of fluvial deposits are reported throughout that area, particularly along the present day valley of the Doubs River (Dreyfuss and Glangeaud 1950; Goguel and Dreyfuss 1965; Dreyfuss and Kuntz 1969; Dreyfuss and Théobald 1972; Contini et al. 1973; Campy 1984). These remnants consist of well-rounded crystalline pebbles, which are commonly found in karst fissures and caves, as colluvial slope deposits, and within terraces of the Doubs River (Fig. 6b). The paleo-hydrographic considerations outlined above (Fig. 5) suggest two possible sources for these remnants: the Middle Pliocene SFC Gravels or the Late Miocene Bois de Raube Formation.

The present-day drainage system of the Rhine-Bresse Transfer Zone (Figs. 4, 5c) that evolved after the PaleoAare was deflected into the Upper Rhine Graben during the Late Pliocene is characterised by two major drainage 


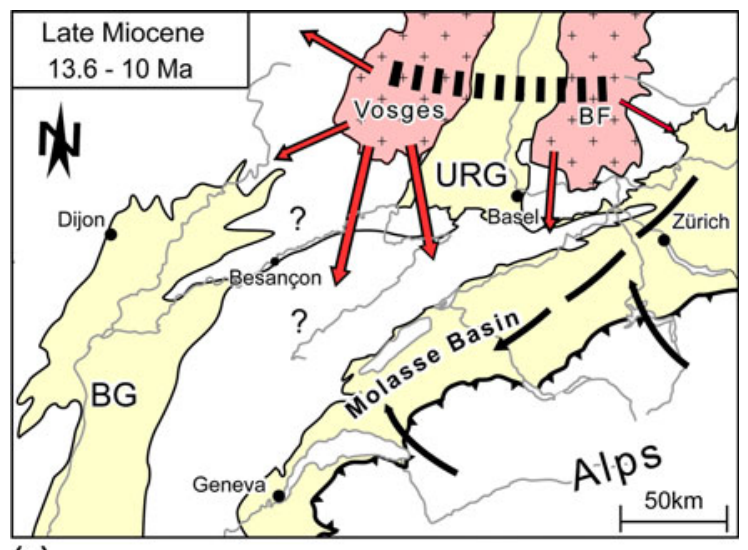

(a)

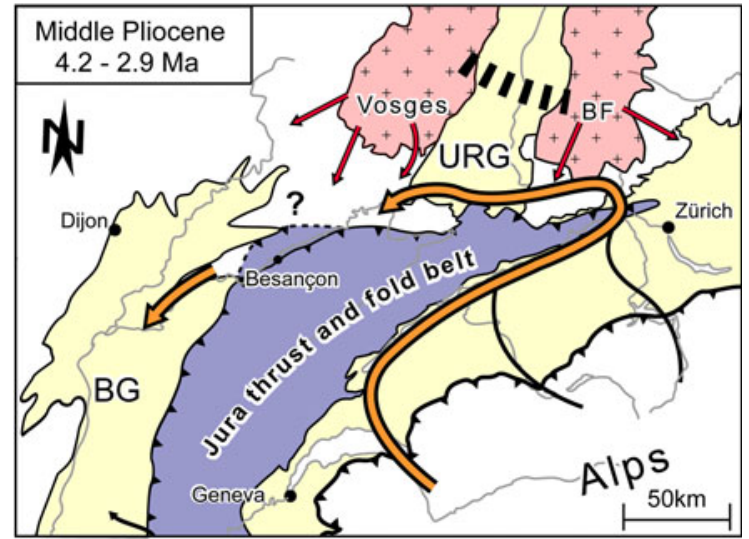

(b)

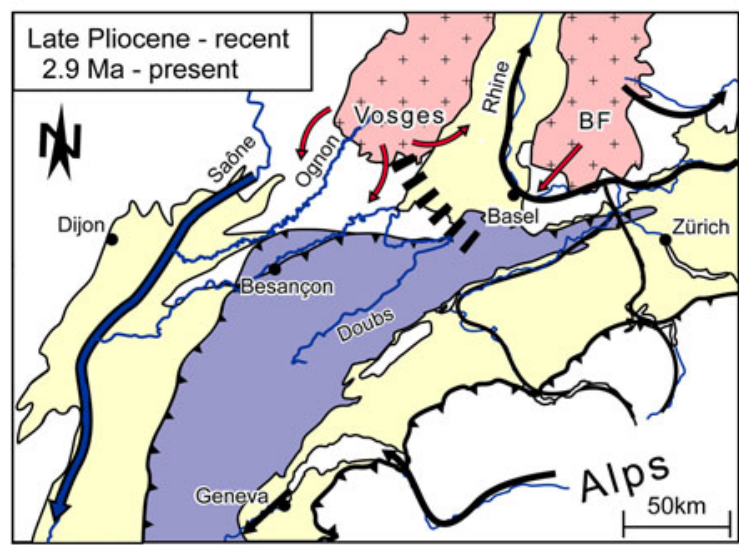

(c)

Fig. 5 Neogene drainage systems of the northwestern Alpine foreland (modified from Giamboni et al. 2004). Thick dashed line marks the major drainage divide between North Sea and the Mediterranean Sea. a During the Late Miocene sediments from the uplifted Vosges Mountains and Black Forest (thick red lines) were shed into the area of the future Jura Mountains. b During the Middle Pliocene the Paleo-Aare (thick orange line) flowed from the Molasse Basin along the deformation front of the Jura fold-and-thrust belt into the Bresse Graben and controlled the deposition of the Sundgau and Forêt de Chaux Gravels c During the Late Pliocene the Paleo-Aare was deflected into the Upper Rhine Graben. The Doubs River that drains the Jura Mountains occupies its former lower reach and drains into the Saône River (thick blue line). BF Black Forest, $B G$ Bresse Graben, $U R G$ Upper Rhine Graben
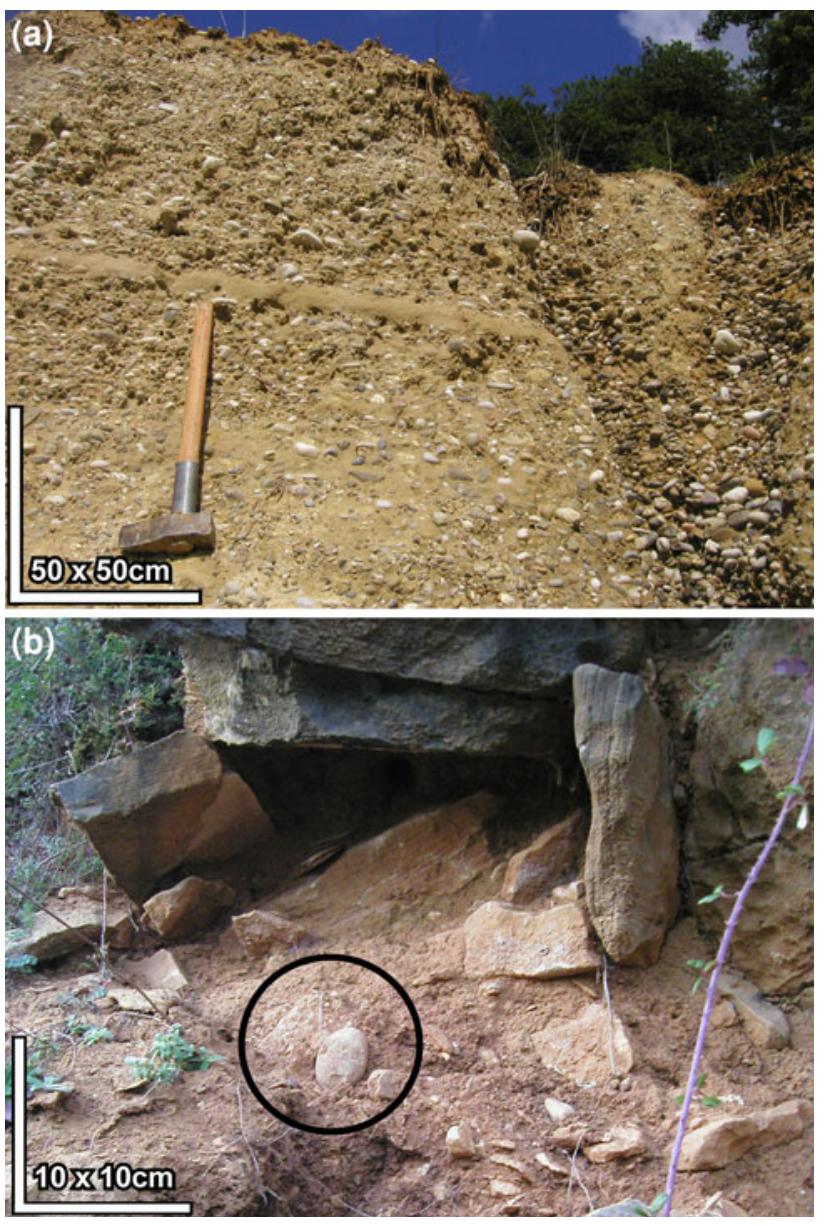

Fig. 6 a Middle Pliocene Forêt de Chaux Gravels (SFC) exposed in the Forêt de Chaux (locality 8 in Fig. 10; Table 1). b Remnants of Miocene and/or Pliocene fluvial gravels occurring in karst fissures or reworked in colluvial and alluvial deposits along the Doubs Valley (locality 3 in Fig. 10; Table 1)

basins, namely those of the Ognon and the Doubs rivers. The Ognon River drains the southwestern Vosges Mountains (Fig. 4). Herein its course is divided into three segments. The upper segment straddles parallel to the prominent NE-SW striking Ognon Normal Fault (Ruhland 1959; Théobald et al. 1977; OGF in Figs. 2, 4). The middle river segment commences where the Ognon River finally crosses the Ognon Normal Fault and from there on flows on its hanging-wall (Figs. 2, 4). Along the lowermost river segment, starting west of the village of Rigney (Fig. 4) the river takes a more westerly course, flowing parallel to the front of the thin-skinned Besançon Zone formed by the Chailluz Thrust and the basement-rooted Avant-Monts Fault (Madritsch et al. 2008). Northwest of the La Serre Horst the Ognon debouches into the Saône River (Fig. 4).

The Doubs River drains large parts of the Jura Mountains (Figs. 2, 4, 5c). Its lower reach leaves the foldand-thrust belt $20 \mathrm{~km}$ south of the city of Montbéliard via the Pont-de-Roide water gap (Fig. 4). Near Montbéliard 
the Doubs bends sharply westward and cuts through the autochthonous Mesozoic succession of the Montbéliard Plateau (Fig. 3), before re-entering the fold-and-thrust belt at the Clerval water gap (Fig. 4). From this point onward the river flows through the Besançon Zone in a narrow canyon sub-parallel to the deformation front of the Faisceau Bisontin. After leaving the thin-skinned fold-andthrust belt downstream of Besançon the valley widens. The Doubs finally flows into the Saône $30 \mathrm{~km}$ southwest of the city of Dole (Fig. 4). As the drainage basins of the Ognon and Doubs developed in different tectonic settings, reconstruction of their Plio-Pleistocene morphologic evolution is likely to reveal potential controlling tectonic processes.

\section{Methodology}

Terrace mapping and digital elevation model analysis

In an effort to develop a robust and consistent database for Plio-Pleistocene deposits covering the entire study area, the terraces along the lower reaches of the Rivers Ognon and Doubs were remapped. This involved a review of published geological maps and subsurface information (Goguel and Dreyfuss 1965; Dreyfuss and Kuntz 1969, 1970; Dreyfuss and Théobald 1972; Contini et al. 1973; Chauve et al. 1979, 1983), own field observations and an analysis of the digital elevation model of the Franche-Comte region (horizontal resolution $50 \mathrm{~m}$ ) using ArcGIS software.

In the field terraces were mapped on the basis of 1:25,000 topographic maps. Sedimentological investigations were mostly restricted to surface observations (size and lithology of fluvial pebbles). Moreover, railroad constructions opened new large-scale outcrops, especially in the lower Ognon Valley, that permitted to examine the lithofacies architecture of the alluvial deposits.

Slope gradient analyses of the digital elevation data further enhance the results of field mapping. A slope of 0 $2^{\circ}$ was attributed to unaltered terrace surfaces. Alluvial surfaces with higher inclinations were regarded as terrace bodies degraded by surface processes and soil creep. Such degraded alluvial surfaces were not further considered as geomorphic markers of former riverbed elevations. Terraces considered juvenile were projected orthogonally onto the course of the river and displayed as longitudinal river profiles extracted from topographic maps.

In an attempt to better characterise the observed valley morphology we calculated geomorphic indices from the digital elevation model. The Valley-Width versus ValleyHeight ratio $\left(V_{\mathrm{f}}\right)$ was used to quantify the incision intensity. It is expressed as

$$
V_{\mathrm{f}}=2 V_{\mathrm{fw}} /\left(\left(E_{\mathrm{ld}}-E_{\mathrm{sc}}\right)+\left(E_{\mathrm{rd}}-E_{\mathrm{sc}}\right)\right)
$$

where $V_{\mathrm{fw}}$ is the width of the valley floor, $E_{\mathrm{sc}}$ is the elevation of the valley floor and $E_{\mathrm{ld}}$ and $E_{\mathrm{rd}}$ are the elevations of the left and right valley divides, respectively (Bull and McFadden 1977). Low $V_{\mathrm{f}}$ values indicate strong incision, while high values characterise broad valleys.

Heavy mineral analysis

Samples for heavy mineral analyses were collected at 19 key locations. These include the Sundgau and Forêt de Chaux gravel surfaces as such, the remnants of fluvial deposits of yet unknown origin and age preserved along the Doubs Valley and alluvial sediments of the Ognon River (Table 1). The latter presently drains the crystalline Vosges Mountains and its foothills, consisting of Devonian to Late Triassic sediments. These deposits are, therefore, representative for a provenance similar to that of the Late Miocene Bois de Raube Formation (Fig. 5a, c).

Heavy mineral analyses were carried out following the guidelines by Boenigk (1983) and Hagedorn (2004). The grain size fraction between 64 and $500 \mu \mathrm{m}$ was obtained from the dissolved samples by wet sieving. Density separation was carried out manually using separatory funnels and Bromoform (density $2.83 \mathrm{~g} / \mathrm{cm} 3$ ) as separation liquid. Meltmount (refraction index: 1.662) was used to embed the heavy minerals onto thin sections. Quantitative heavy mineral counting using a polarisation microscope was performed according to the line count method. Per sample a minimum of 100 grains were counted.

Due to a high content in organic matter and carbonate minerals as well as the occurrence of Fe-hydroxide crusts, some samples were treated hydro-chemically before heavy mineral separation (Table 1). Hydrogen peroxide $\left(\mathrm{H}_{2} \mathrm{O}_{2}\right)$ was used to destroy organic matter and clay minerals and to disintegrate the samples prior to sieving. In addition, some samples were treated with boiling $\mathrm{HCl}$ acid (conc.: 25\%) to dissolve carbonate minerals and Fe-hydroxide crust. Samples showing very high amounts of opaque minerals were separated using an automatic magnetic separation device. Possible effects of hydro-chemical treatment and magnetic separation on the counting results were crosschecked with untreated aliquots of the same sample.

\section{Results}

Terrace systems and morphology of the lower Ognon and Doubs Valley

\section{Ognon Valley}

The terraces of the Ognon Valley are built up by a diverse alluvial succession that reaches a thickness of up to $50 \mathrm{~m}$ in 


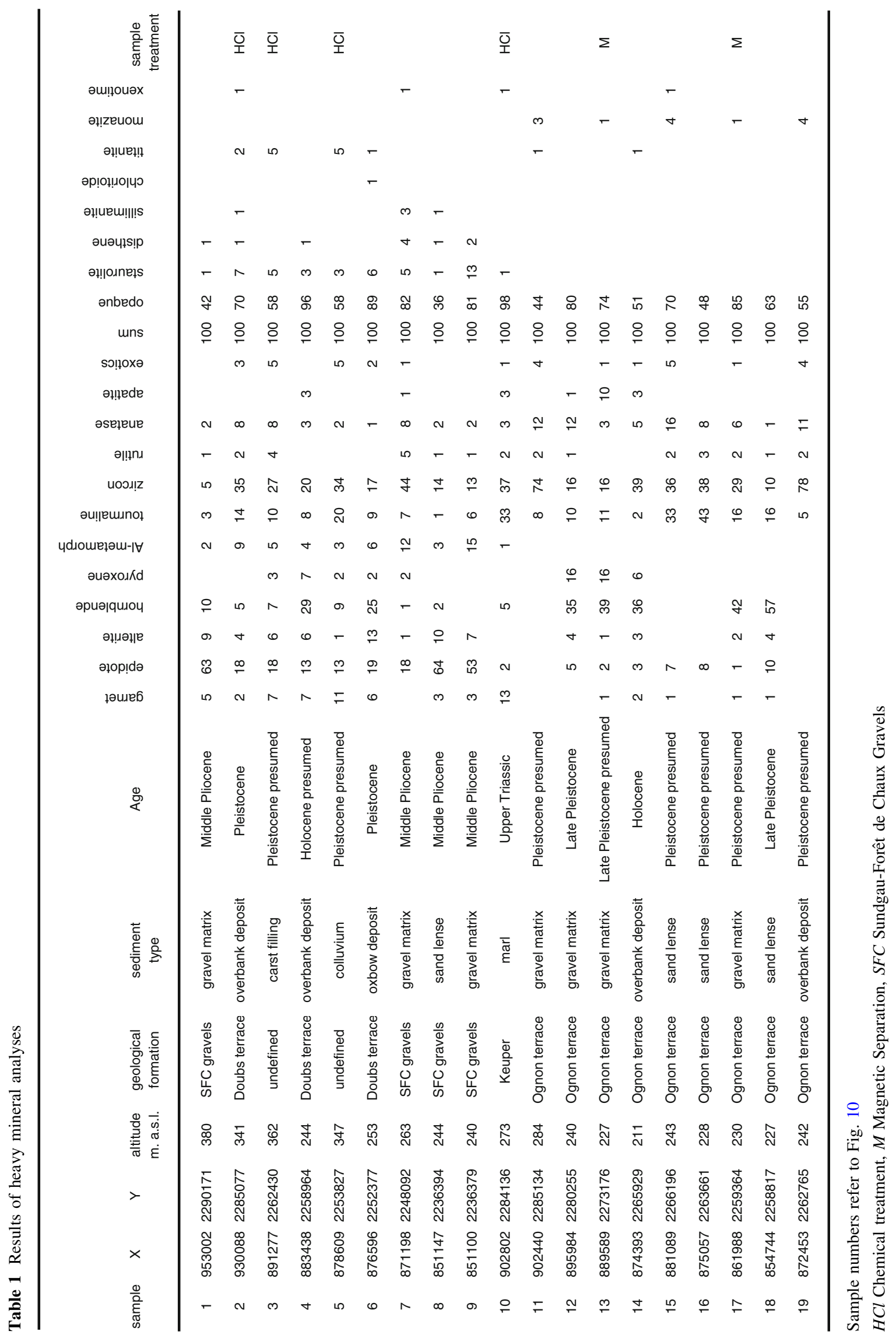




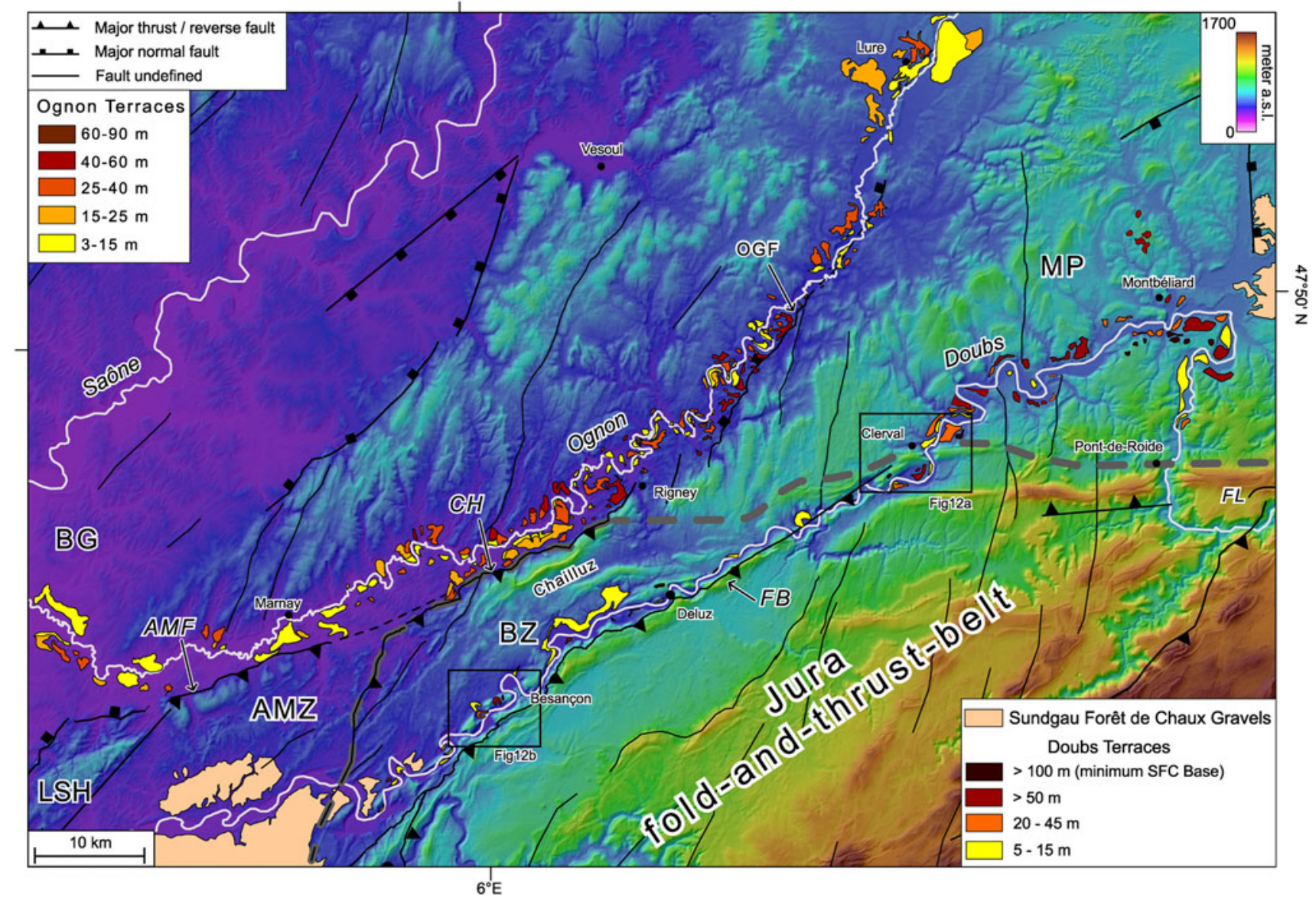

Fig. 7 Digital elevation model and map of the alluvial terraces along the Ognon and Doubs Valley indicating the elevations of terraces above the active river channel. $A M F$ Avant-Monts Fault, $A M Z$ AvantMonts Zone, BZ Besançon Zone, FB Faisceau Bisontin, FL Faisceau

the lowermost Ognon Valley near the village of Marnay (Dreyfuss and Kuntz 1969; Chauve et al. 1983; Campy and Contini 1981; Fig. 7). The basal sedimentary sequence consists of a thick succession of clays of probable Pliocene age that were deposited in a lacustrine environment (Dreyfuss and Kuntz 1969; Chauve et al. 1983). These homogeneous clays are overlain by a complex series of gravels, sands, silts and clays that build up the Upper and Lower Ognon terraces and indicate a more dynamic fluvial depositional environment (Dreyfuss and Théobald 1972; Chauve et al. 1983; Madritsch 2008).

The results of revised terrace mapping in the Ognon Valley are shown in Fig. 7. Apart from the present-day flood plain, up to five different terrace levels are distinguished on the basis of their elevation above the active channel. Due to the lack of sufficiently dense age information no temporal correlation of these terrace levels along the river is attempted in this study. Instead, we only examine the spatial distribution of terraces along the longitudinal river profile which yields information on its incision history (Fig. 8).
Lomont, LSH La Serre Horst, MP Montbéliard Plateau. The thick, grey, dashed line marks the front of the thin-skinned Jura fold-andthrust belt

These observations are complemented by Valley-Height versus Valley-Width ratios $\left(V_{\mathrm{f}}\right)$ that were calculated at roughly $10 \mathrm{~km}$ intervals along the valley.

While the upper segment of the Ognon Valley straddles the trace of the Ognon Normal Fault the middle and lower segments exclusively occupy the hanging-wall of this fault (Figs. 2, 4, 7). The upper valley segment is characterised by a low sinuosity to straight channel pattern. The uppermost section of this stream segment is deeply entrenched into the Paleozoic rocks of the Vosges Mountains. Further downstream the river occupies a broad plain characterised by fluvio-glacial sediments (Thiébaut et al. 1974; Mercier and Jeser 2004). The middle segment of the Ognon, which commences after the river has ultimately crossed the Ognon Normal Fault, is characterised by a high-sinuosity channel that progressively incised into its substratum as evidenced by a distinctive succession of up to five alluvial terrace levels (Figs. 7, 8). Along this segment the depth of the valley is about $60 \mathrm{~m}$. Along the lower valley segment, southwestward from Rigney, river incision was less intense 
Fig. 8 Longitudinal profile of the Ognon River (vertical exaggeration: 200). Terraces along the northern and southern flanks of the valley (Fig. 7) were projected orthogonally onto the profile. Also shown are $V_{\mathrm{f}}$ ratios calculated at about $10 \mathrm{~km}$ intervals along the valley

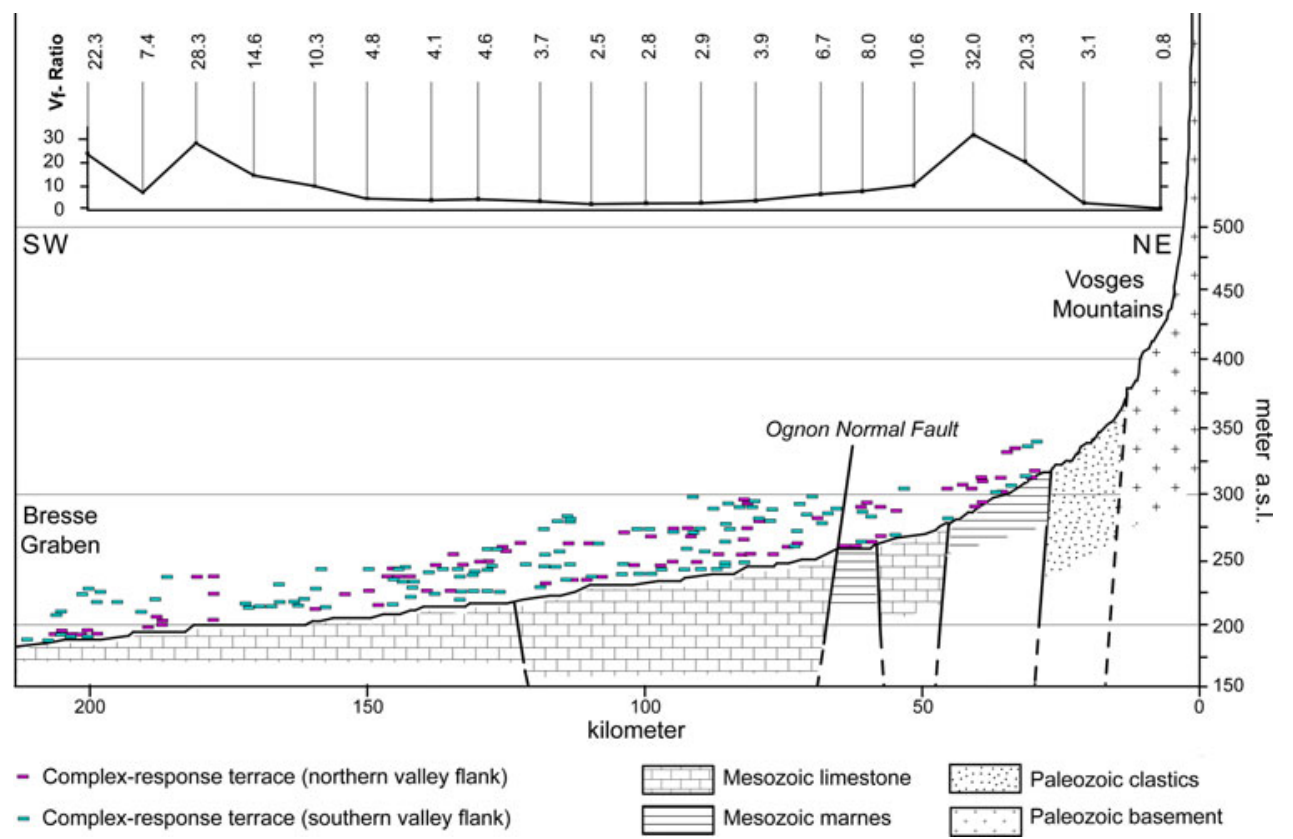

as indicated by the terrace distribution and the $V_{\mathrm{f}}$ indices (Figs. 7, 8).

The terrace distribution along the Ognon Valley is asymmetric (Fig. 8). Systematically, more terrace levels are preserved on the southern flank of the valley in comparison to the northern side (Campy and Contini 1981).

\section{Lower Doubs Valley}

The results of the morphological analysis of the lower Doubs Valley are illustrated in Figs. 7 and 9. A well-pronounced aggradational terrace succession is only preserved between the water gaps of Pont-de-Roide and Clerval, where the meandering river cuts through the autochthonous Mesozoic series of the Montbéliard Plateau (Fig. 7). The incision intensity along this river segment is moderate as shown by high $V_{\mathrm{f}}$ ratios (Fig. 9). The uppermost terraces are most often bedrock strath surfaces on which remnants of fluvial deposits are preserved. Comparison of the elevation of these surfaces with that of the nearby SFC gravel plain to the east in the Sundgau area (Figs. 7, 9) suggests that they represent the minimum elevation of the former base of the SFC-gravel plain. Below this erosional surface, up to three aggradational terrace levels can be distinguished. The two upper levels at about 20-45 and 50-75 m above the active channel (Figs. 7,9) often consist of coarse gravels. Contini et al. (1973) concluded from the pebble spectra of these terrace deposits that they either represent or were derived from the Middle Pliocene SFC Gravels. The lowermost terraces along this segment of the Doubs are located 5-10 $\mathrm{m}$ above the active channel and are characterised by a larger percentage of limestone clasts (Goguel and Dreyfuss 1965; Contini et al. 1973).
Downstream from the Clerval water gap (Figs. 7, 9) the incision intensity changes drastically as illustrated by the $V_{\mathrm{f}}$ ratio. Whilst the Doubs maintained a fairly high sinuosity, it deeply incised into the limestone bedrock and carved out a narrow canyon. Strath terraces are commonly preserved along this valley segment, whereas aggradational terraces composed of coarse gravels occur only rarely. Reports of fluvial deposits located more than $250 \mathrm{~m}$ above the active river channel (Dreyfuss and Glangeaud 1950; Goguel and Dreyfuss 1965) could be confirmed during this study (Figs. 6, 9, 10). Spectacular paleo-meanders which formed during river incision are best preserved near the city of Besançon (Dreyfuss and Glangeaud 1950; Chauve et al. 1983; Madritsch 2008). All preserved paleo-meanders systematically face towards the south, indicating that they were formed by combing during a progressive southward shift of the river course (Holbrook and Schumm 1999). Differential incision of the Doubs River along its course is also evident from the elevation of terraces above the active channel. Terrace elevations are significantly higher along the section where the Doubs flows through the Besançon Zone and where incision has been strongest (Fig. 9).

About $15 \mathrm{~km}$ downstream from the city of Besançon, the Doubs leaves the thin-skinned Jura-fold-and-thrust belt. From that point onwards it incises into the Middle Pliocene Forêt de Chaux Gravels and the underlying Jurassic limestones. Along this sector the $V_{\mathrm{f}}$ ratios indicate moderate incision intensity.

\section{Provenance analysis}

The regional comparative heavy mineral analyses carried out during this study permit to determine the provenance of 
Fig. 9 Longitudinal profile of the lower Doubs River (vertical exaggeration: 200) starting from the water gap of Pont de Roide (Fig. 4). Terraces of the northern and southern valley flank (Fig. 7) were projected orthogonally onto the profile. Also shown are $V_{\mathrm{f}}$ ratios calculated at roughly $10 \mathrm{~km}$ intervals along the valley. $\mathrm{CH}$ Chaudanne wind gap, MAC Malcombe paleomeander, $V E L$ Velotte paleomeander, $R D O$ Roche d'Or paleomeander, SFC SundgauForêt de Chaux Gravels

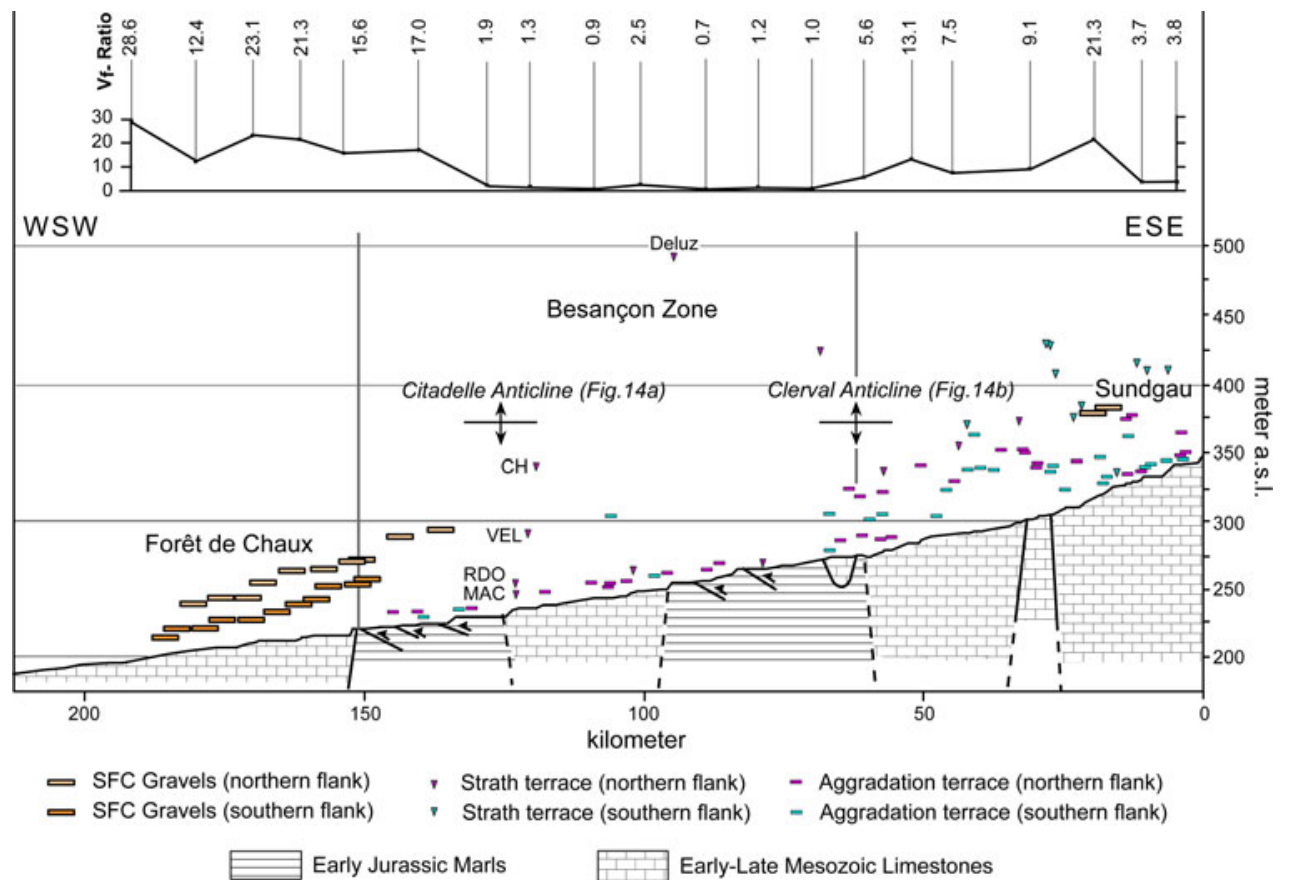

fluvial sediments preserved in the Doubs and Ognon Valleys. Results are summarised in Fig. 10 and Table 1. The most common heavy minerals detected are garnet, epidote, hornblende, tourmaline and zircon. Also common in some samples are anatase, augite and aluminium-rich silicates typical for medium- to high-grade metamorphic terrains that are given as Al-metamorphics in Fig. 10 (mostly staurolite and subordinately disthene and sillimanite, see Table 1). Apatite, rutile and other rare minerals occur only in minor percentages. Unidentified heavy mineral fragments (fine grained aggregates or altered heavy minerals) were also counted and summed up as alterite in Table 1 and Fig. 10.

The samples from the Plio-Pleistocene terraces of the Ognon River reveal two distinctly different heavy mineral assemblages. Samples of the Upper Ognon terraces (samples $11,15,16,19)$ are characterised by a very high percentage of stable heavy minerals (minimum of 50\%, sometimes more than $75 \%$ ), namely zircon and tourmaline as well as anatase and rutile. Unstable heavy minerals such as epidote make up a subordinate fraction only. Garnet has hardly ever been observed except in the Fouchères area located southeast of Marnay where also significant amounts of hornblende were found (sample 17, see Figs. 4, 10; Table 1). Lower Ognon terrace sediments show different and diversified heavy mineral spectra (e.g. sample 12-14, 18). These samples are rich in unstable heavy minerals (about 50\%) and are characterised by large amounts of hornblende (more than 25\%). Most samples also contain pyroxene (sample 12-13).
Systematic heavy mineral analyses of sediments from different catchments of the southern Upper Rhine Graben showed that heavy mineral assemblages such as those from the Ognon Valley are typical of sediments derived from the crystalline basement and Mesozoic cover of the Vosges Mountains (Van Andel 1950; Hagedorn 2004; Hagedorn and Boenigk 2008). A typical "Alpine" heavy mineral assemblage (Boenigk 1987; Bonvalot 1974; Liniger and Hofmann 1965), defined by the dominance of garnet, epidote, hornblende and the occurrence of medium-grade to high-grade metamorphic minerals (staurolite, kyanite), has not been detected in any of the samples from the Lower Ognon Valley.

Samples from gravels of the Sundgau and Forêt de Chaux areas (sample 1,7-9) show similar heavy mineral spectra, thus testifying to their genetic relation (Liniger and Hofmann 1965; Bonvalot 1974; Petit et al. 1996). In both areas high amounts of epidote, as well as the occurrence of hornblende, garnet and staurolite define the characteristic "Alpine" heavy mineral spectrum that is typical for the Paleo-Aare braided river system (Liniger and Hofmann 1965; Hagedorn 2004).

Samples taken from remnants of fluvial deposits and terrace sediments along the Doubs Valley (samples 2-6) revealed a similar heavy mineral assemblage as those from the Sundgau and Forêt de Chaux Gravels. They are characterised by a relatively high percentage of unstable minerals, particularly epidote, but also contain significant amounts of hornblende and garnet. Most notably, staurolite occurs in all of these samples. 


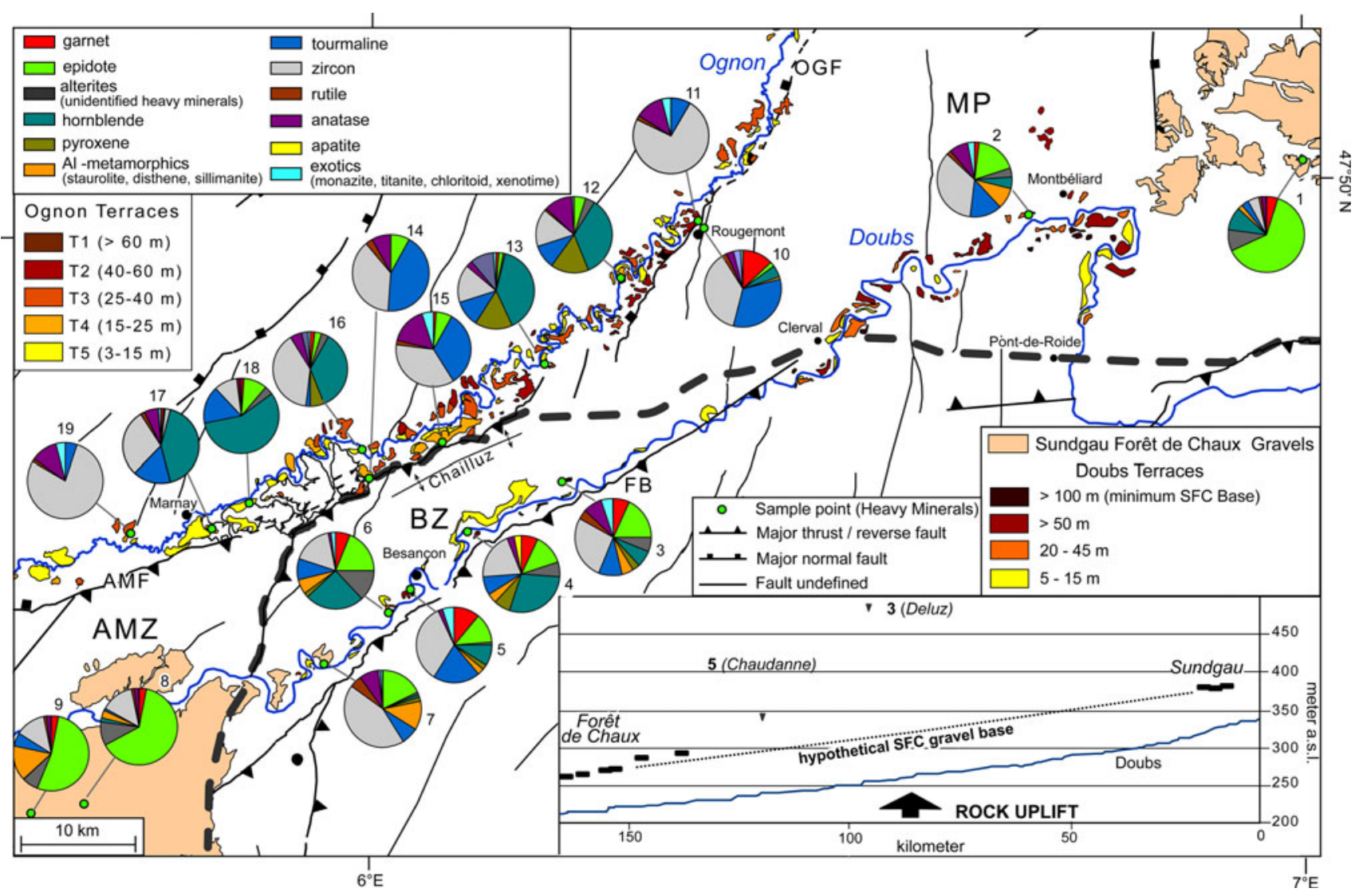

Fig. 10 Results of regional heavy mineral analyses. The thick, grey, dashed line marks the boundary of the Jura fold-and-thrust belt. The inset in the lower right shows a segment of the longitudinal Doubs river profile starting at the water gap of Ponte-de-Roide. The elevation of the base of the continuous gravel plain in the Sundgau and Forêt de Chaux areas and of gravel remnants detected along the

Unlike the samples from the Sundgau area, the samples from the Doubs Valley are also rich in zircon and tourmaline. These differences in heavy mineral spectra can be explained by contributions from tributaries originating in the Vosges Mountains to the SFC braided river system (Théobald et al. 1976). The sedimentary load of these tributaries was derived from the Triassic cover of the Vosges Mountains, characterised by high amounts of stable minerals such as zircon and tourmaline (Hagedorn 2004; Hagedorn and Boenigk 2008; compare sample 10), diluting the original "Alpine" heavy mineral spectrum of the SFC-Gravels. These Vosgian tributaries already contributed to the Middel Pliocene Paleo-Aare and thus, are probably responsible for the higher zircon content of samples from the Forêt de Chaux area (13-14\%) as compared to those from the Sundgau area $(5 \%)$. Their contaminating effect increased further during the Late Pliocene and Early Quaternary after the Paleo-Aare River had been diverted into the Upper Rhine Graben and the early Doubs River, influenced by Vosges tributaries entering it near the
Doubs Valley were projected orthogonally onto the profile. Refer to text for further discussion. AMF Avant-Monts Fault, AMZ AvantMonts Zone, $B$ Besançon, $B G$ Bresse Graben, $B Z$ Besançon Zone, $F B$ Faisceau Bisontin, $M$ Montbéliard, MP Montbéliard Plateau, OGF Ognon Fault

city of Montbéliard, reworked the SFC-Gravels in the study area (Fig. 5c; Ziegler and Fraefel 2009). This interpretation explains why the "Alpine" heavy mineral spectra of samples from the Doubs Valley are characterised by higher amounts of zircon and tourmaline as compared to samples from the Forêt de Chaux area further downstream.

In addition, the effects of weathering of fluvial remnants must be taken into consideration, though these effects are probably of minor importance only. Higher weathering resistance of stable heavy minerals (Boenigk 1983) presumably led to a relative enrichment in reworked sediments. Systematic heavy mineral analyses of Sundgau Gravel weathering profiles have shown that garnet is often relatively depleted from the spectrum compared to the amount of epidote when strong weathering occurred (Boenigk 1982, 1987). In carbonate-rich sediments, however, weathering of garnet is reduced (Sindowski 1949). This is compatible with the fact that the carbonate-rich samples from the Doubs Valley (e.g. sample 3-5; see Fig. 10; Table 1) show higher amounts of garnet in 
comparison to the samples taken from the Sundgau and the Forêt de Chaux areas which are poor in carbonate.

In summary, heavy mineral analyses indicate that the fluvial deposits of the Ognon Valley were exclusively sourced by the Vosges Mountains. They clearly differ from the samples of the Doubs Valley. Despite some differences, similarities between the heavy mineral spectra of the latter samples and those from the Middle Pliocene SFC Gravels are obvious, particularly concerning the high amounts of epidote and the occurrence of staurolite. The fluvial remnants from the Doubs Valley bear a distinct signature of Alpine provenance and were by no means exclusively derived from the Vosges Mountains. Thus, the results clearly indicate that these deposits are not directly related to the Late Miocene Bois de Raube Formation but represent SFC Gravels that were reworked and contaminated by the early Doubs River during the Late Pliocene-Pleistocene.

\section{Discussion}

Paleo-topographic reconstruction of the Sundgau-Forêt de Chaux gravel base and implications

for post-Pliocene rock uplift

The results of the heavy mineral analyses permit attributing the remnants of fluvial deposits along the Doubs Valley to the eroded Middle Pliocene Sundgau-Forêt de Chaux (SFC) Gravels. The elevation of these remnants marks the minimum altitude of the base of the SFC gravel sheet and, therefore, the Middle Pliocene paleo-topography. The inset in Fig. 10 shows a segment of the longitudinal river profile of the Doubs that connects the continuous SFC gravel plains of the Sundgau and Forêt de Chaux areas. The base of the SFC gravel plain, as well as the elevations of SFC remnants identified by heavy mineral analyses, was orthogonally projected onto the longitudinal river profile. The stippled line marks the presumed undeformed base of the former SFC gravel plain linking the Sundgau and the Forêt de Chaux areas.

Remnants of SFC Gravels identified in the Doubs Valley are located up to $170 \mathrm{~m}$ above the extrapolated regional gravel base. The maximum thickness of the SFC Gravels amounting to only 30-65 $\mathrm{m}$ cannot account for this elevation difference. This indicates that erosion of the SFC Gravels in the area between the Sundgau and the Forêt de Chaux resulted from relative rock uplift, as already proposed by Campy (1984). Biostratigraphic constraints on the age of deposition of the SFC Gravels (4.2-2.9 Ma; Petit et al. 1996; Fejfar et al. 1998) indicate that this uplift occurred during Late Pliocene to Pleistocene times, after thin-skinned deformation of the Jura fold-and-thrust belt has presumably ceased. Furthermore, these age constraints indicate a minimum Late Pliocene to recent uplift rate of $0.05 \pm 0.02 \mathrm{~mm} /$ year. This rate is in good agreement with result from nearby areas (Müller et al. 2002; Giamboni et al. 2004b; Ustaszewski and Schmid 2007).

Based on the highest elevations at which SFC gravel remnants occur and on the results of heavy mineral analyses, we reconstructed the Middle Pliocene paleo-topography of the RBTZ using an ArcGIS kriging interpolation (Fig. 11). Taking into account sedimentological and
Fig. 11 Paleo-topographic reconstruction of the eroded Paleo-Aare channel linking the Sundgau and Forêt de Chaux gravel sheets as deduced from the results of heavy mineral analyses. $A M F$ Avant-Monts Fault, $A M Z$ Avant-Monts Zone, $B G$ Bresse Graben, $B Z$ Besançon Zone, $\mathrm{CH}$ Chailluz Thrust, $F B$ Faisceau Bisontin, $F L$ Faisceau du Lomont, $F Q$ Faisceau de Quingey, $M P$ Montbéliard Plateau, LSH La Serre Horst, $O G F$ Ognon Fault, $U R G$ Upper Rhine Graben

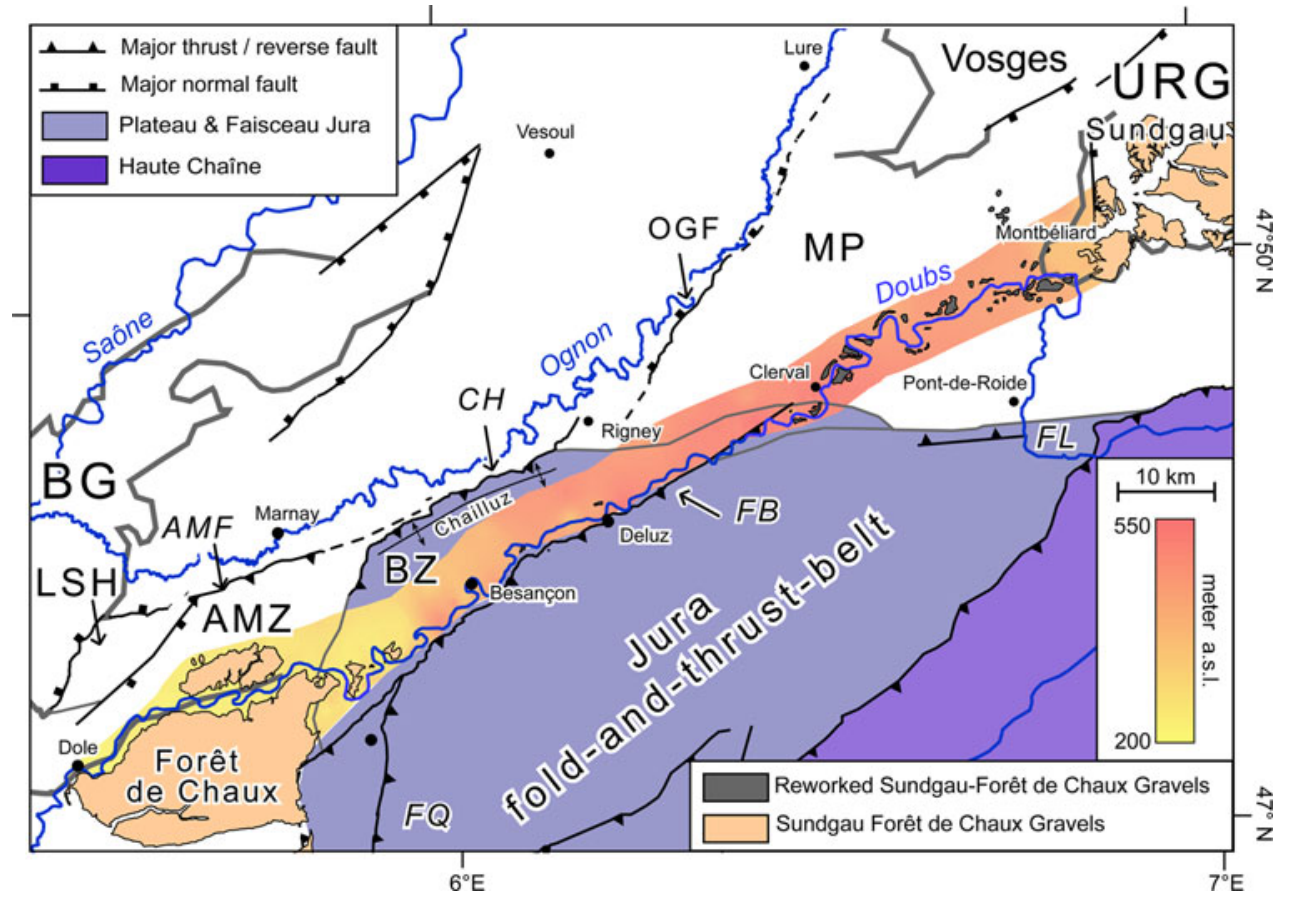


geomorphic observations in neighbouring areas (Liniger 1966; Bonvalot 1974; Giamboni et al. 2004a) we considered the undeformed SFC gravel sheet to reflect a rather flat, i.e. low gradient surface. Well constrained data points for the interpolation are provided by the base of the Sundgau and Forêt de Chaux gravel sheets and the elevated SFC remnants preserved along the Doubs Valley. At any given point, the most elevated remnants determine the minimum elevation of the erosional gravel base.

As SFC remnants are scarce in the area, we also considered the results of heavy mineral analysis to better constrain the paleo-geographic extent of the SFC-braided river system. The reconstructed Paleo-Aare channel in which the SFC Gravels were deposited follows the ENE-WSW striking structural grain of the region and was confined by structures of the thin-skinned Jura fold-and-thrust belt (Fig. 11).

Whilst the southeastern boundary of the channel is well defined and coincides with the deformation front of the Faisceau Bisontin, its precise width and extent to the northwest are less well constrained. The model shown in Fig. 11 assumes that the width of the braided Paleo-Aare River was more or less constant. In any case, the PaleoAare channel did not reach beyond the décollement related Chailluz Anticline into the Lower Ognon Valley. This is well constrained by the observation that alluvial deposits from the Lower Ognon Valley are devoid of Alpinederived heavy minerals (Fig. 10). Hence, the Ognon Valley formed a separate drainage basin that was only sourced by the Vosges Mountains and their foothills already in Middle Pliocene times. This is in agreement with regional paleogeographic reconstructions (Sissingh 1998). Moreover, no reworked SFC Gravels were shed into the Ognon Valley during the post-Pliocene uplift of the area. Therefore, the Chailluz Anticline most likely formed a pre-existing structural divide between the drainage basins of the PaleoAare and the precursor of the Ognon River during the Middle Pliocene. Some reworked material of the SFC gravel plain may have been transported around the SW plunge of the Chailluz Anticline and shed into the lowermost Ognon Valley, leading to the deposition of fine grained gravels in the Fouchères area southeast of Marnay (Figs. 4, 10). Dreyfuss and Kuntz (1969) interpreted these sediments as being related to the SFC Gravels based on the presence of Alpine detritus (Fig. 4). However, this observation could not be confirmed by our heavy mineral analyses (Fig. 10; Table 1, samples 2, 7, 9, 17).

Response of Pleistocene to recent drainage basins

\section{Ognon Valley}

The morphologic and sedimentological record of the Ognon Valley points to the presence of a complex-response terrace system which is characterised by alternating phases of sediment aggradation and degradation (Bull 1990). Such a scenario is also indicated by the results of the heavy mineral analyses. Whilst no traces of Alpine-derived material were detected, suggesting that all the terrace sediments along the valley were derived from the Vosges Mountains, heavy mineral data from different terrace levels indicate slight source area variations. These variations possibly relate to different aggradation phases that were interrupted by phases of moderate river incision and possibly to progressive unroofing of the Vosges Mountains (Madritsch 2008).

Tectonic effects on the valley evolution may be deduced from the terrace distribution, the incision pattern and the drainage geometry. A relation of these parameters with the prominent Ognon Normal Fault is evident (Figs. 7, 8). The $V_{\mathrm{f}}$ ratio rises significantly once the river finally crosses this fault and moderately incises into its hanging wall forming up to five terrace levels. This suggests a late-stage mild inversion of the Ognon Normal Fault.

As inferred from the independent investigations of the northern and southern valley flanks, the distribution of terraces along the Ognon Valley is asymmetric (Figs. 7, 8). Campy and Contini (1981) who also made this observation interpreted it as resulting from a northward-directed lateral shift of the Ognon River in response to tectonic uplift along the southward adjacent front of the Jura fold-and-thrust belt. Presumably, this shift caused the preferential erosion and development of terraces along the northern and southern valley flanks, respectively (Campy and Contini 1981; Campy 1984). Therefore, the Ognon Valley was only marginally affected by the processes that led to the more or less contemporaneous degradation of the SFC-Gravels in the lower Doubs Valley.

\section{Lower Doubs Valley}

The incision pattern of the Doubs Valley is clearly related to the outlines of the tectonic units (Figs. 7, 9). Upon reentry of the Doubs into the Jura fold-and-thrust belt at the Clerval water gap its incision intensified significantly (Figs. 7, 9). As apparently hardly any sediment aggradation occurred during Late Pliocene and Pleistocene, strath terraces, such as paleo-meanders predominate. The symmetric orientation of paleo-meanders along the valley indicates that the Doubs River shifted slightly southward during its incision. This may imply a gentle southward tilt of the Doubs Valley. During its incision, the river reworked the Late Pliocene SFC gravel plain, the erosional base of which is marked by SFC-gravel remnants. Some of these remnants were detected on the crests of anticlines and are located up to $250 \mathrm{~m}$ above the present valley floor (e.g. Deluz; Chaudanne, Fig. 9). 


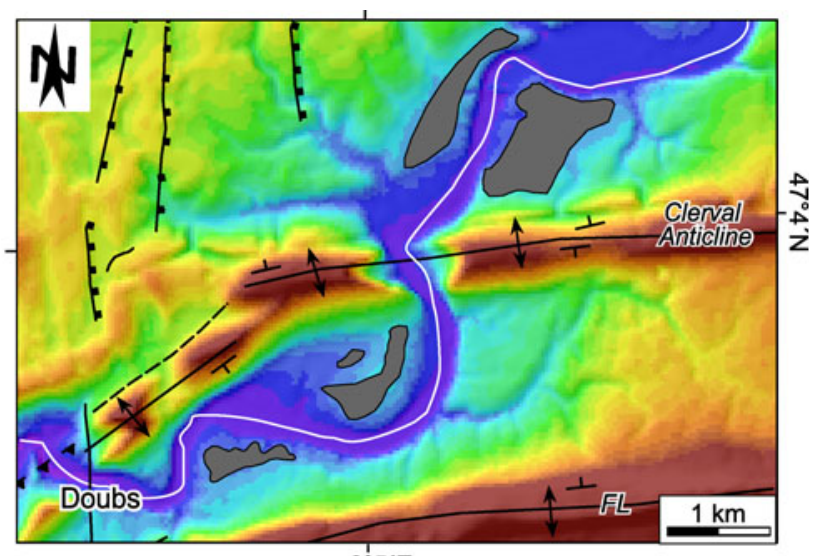

(a)

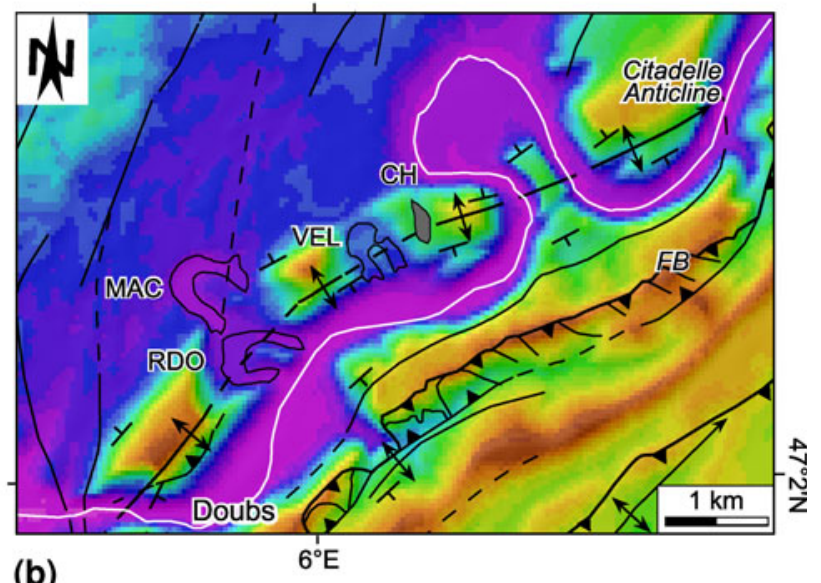

(b)

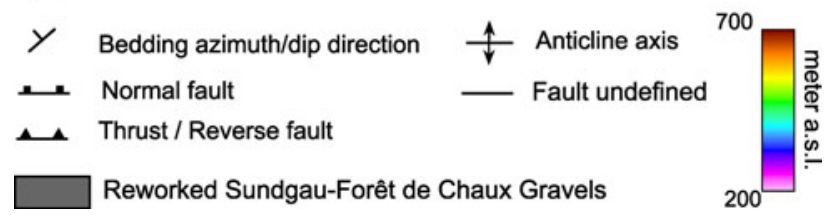

Fig. 12 Examples of possibly erosion-related late-stage folding along the Doubs Valley (see Fig. 7 for location). a The Clerval Anticline is dissected by the Doubs in an antecedent manner. Coarse SFC Gravels, most likely reworked by the Doubs, are found to the north and south of the anticline, suggesting that fold growth occurred after the deposition of the gravels and establishment of Doubs River course. b Pleistocene growth of the Citadelle Anticline is evidenced by differential uplift of paleo-meanders along its axis (modified after Madritsch 2008). Note that Middle Pliocene Sundgau-Forêt de Chaux (SFC) Gravels were detected in the Chaudanne wind gap on the crest of the anticline (see also Fig. 9). $C H$ Chaudanne wind gap, FB Faisceau Bisontin, FL Faisceau du Lomont, MAC Malcombe paleomeander, $R D O$ Roche d'Or paleo-meander, VEL Velotte paleomeander

Folding continued during the Pleistocene incision of the Doubs River. The Clerval Anticline (Fig. 12a) is dissected by the Doubs in an antecedent manner. Coarse SFC Gravels, most likely reworked by the Doubs, are found to the north and south of the anticline, suggesting that fold growth continued after the deposition of the gravels and establishment of the Doubs River course. Along the
Citadelle Anticline active folding is recorded by differentially uplifted paleo-meanders (Dreyfuss and Glangeaud 1950; Madritsch 2008; Fig. 12b). In this area, the incision of the meandering river was apparently structurally focused as its course was locked between Citadelle Anticline and the fault related folds of the Faisceau Bisontin. This process was further amplified where the river reached the easily erodable Late Triassic to Early Jurassic marls and clays in the anticlinal cores. This prevented its deflection from the growing fold.

\section{Tectonic implications}

Based on the erosion and preservation pattern of the SFG Gravels and the variable geomorphic evolution of the Ognon and Doubs drainage basins a zone of Plio-Pleistocene differential rock uplift can be identified in the area of the RBTZ (Fig. 11). This zone can be correlated to structural units and is thus partly controlled by tectonic processes.

To the northeast and southwest the uplifted zone is bounded by the Upper Rhine and Bresse Grabens, respectively. Whilst on the flanks of these grabens the SFC Gravels are still well preserved they were eroded throughout the RBTZ (Fig. 4). Thus, the central RBTZ was relatively uplifted during the latest Pliocene and Pleistocene with respect to the Upper Rhine and Bresse grabens, parts of which subsided during this time interval (Ziegler and Dèzes 2007). The NW to SE extent of the uplifted area is defined by the evolution of the Ognon and Doubs Valley along a schematic NW-SE trending cross-section through the Besançon Zone (Fig. 13), the part of the Jura fold-andthrust belt that encroached onto the pre-existing normal fault system of the RBTZ and the underlying Burgundy Trough, and its foreland (Madritsch et al. 2008; Figs. 2, 3). The section shown in Fig. 13 is roughly parallel to the structural transect presented in Fig. 3 and also to the orientation of the present-day maximum horizontal stress trajectories (Becker 2000; Kastrup et al. 2004; Reinecker et al. 2005).

During the Middle Pliocene (Fig. 13a) the Lower Ognon Valley and the precursor of the Doubs Valley were characterised by sediment aggradation. The Ognon Valley developed as a lacustrine basin along the southwestward adjacent Ognon Normal Fault, the décollement related Chailluz Anticline and the basement-rooted Avant-Monts Fault (Madritsch et al. 2008). Fluvial sediments were later shed into this basin from the foothills of the Vosges Mountains. South of the Chailluz Anticline, the Paleo-Aare occupied the area of the future Doubs Valley and deposited the Middle Pliocene SFC Gravels (Figs. 11, 13a). The observation that the Chailluz Anticline formed a structurally controlled drainage divide between the Lower Ognon 
Fig. 13 Schematic crosssection (not to scale) through the central part of the study area illustrating its Plio-Pleistocene tectono-geomorphic evolution (see Fig. 4 for approximate location). a Middle Pliocene aggradation of the SundgauForêt de Chaux (SFC) Gravels. The apparently pre-existing main structures related to the thin-skinned Jura fold-andthrust belt define drainage basin boundaries. b Late Pliocene contractional thick-skinned deformation contributes to differential uplift of the Besançon Zone and erosion of the SFC Gravels. The Ognon River migrates northwestward in response to relative uplift to the south (Campy and Contini 1981). c Locally sustained active folding within the Jura fold-and-thrust belt apparently occurs in relation to enhanced incision of the Doubs River

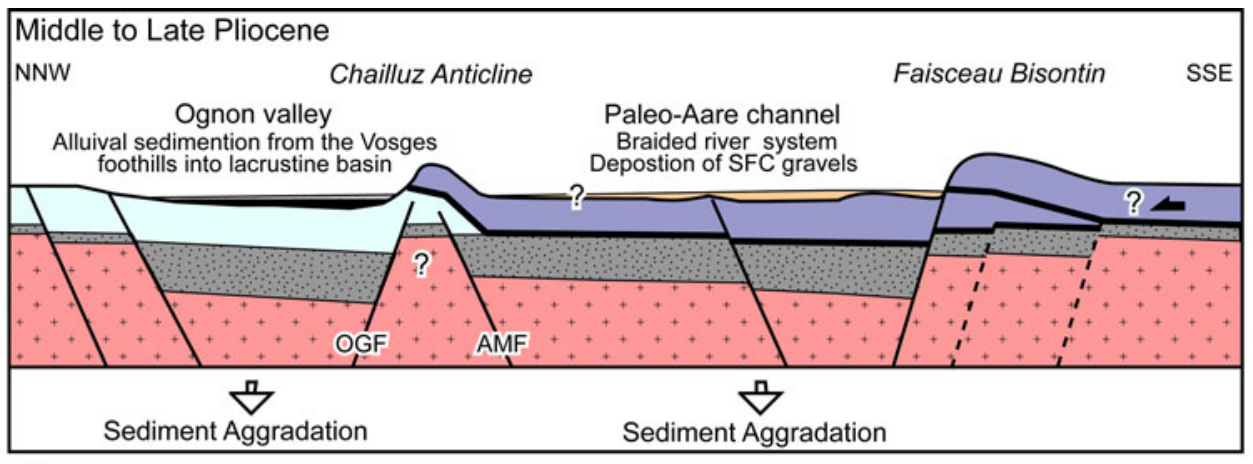

(a)

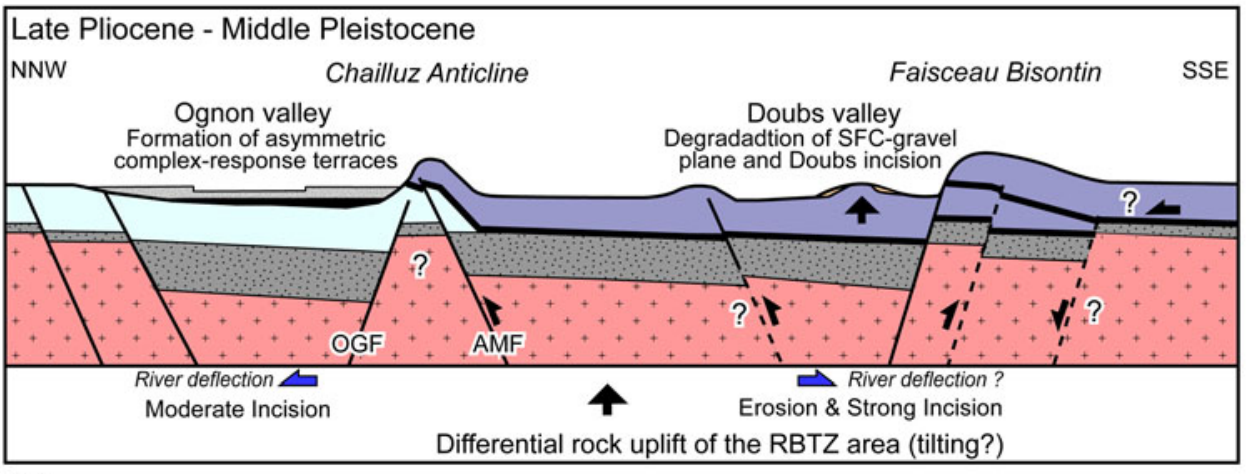

(b)

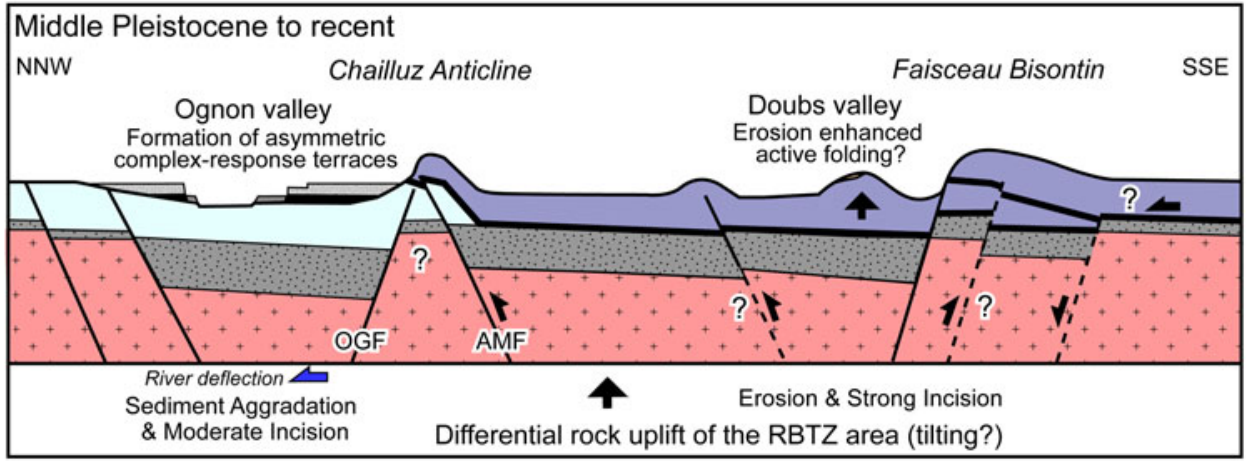

(c)

\begin{tabular}{|l|l}
\hline Lower Ognon deposits (Middle-Late Pleistocene) & Mesozoic undiff. (Burgundy Platform) \\
\hline Upper Ognon deposits (Pliocene- Middle Pleistocene?) \\
Lacrustine deposits (Late Miocene - Early Pliocene?) \\
\hline Sundgau-Forêt de Chaux gravels (MiddlePliocene)
\end{tabular}

Valley and the Paleo-Aare gravel plain (Fig. 11) leads to the hypothesis that the Chailluz Anticline essentially predates the onset of the Middle Pliocene SFC Gravel deposition and began to grow already during the main phase of thin-skinned Jura deformation (10.5-4.2 Ma; Ustaszewski and Schmid 2006; Madritsch et al. 2008). This probably also applies for the deformation front of the Faisceau Bisontin that formed the southern boundary of the SFC gravel plain (Fig. 13a).

At around 2.9 Ma (Late Pliocene Fig. 13b) the PaleoAare was deflected into the Rhine Graben. The study area was, thus, cut off from Alpine sediment supply and deposition of SFC Gravels ceased. The former valley of the Paleo-Aare then became occupied by the precursor of the Doubs River (Figs. 5b, 7). At the same time, the RBTZ was relatively uplifted with respect to the adjacent Upper Rhine and Bresse Grabens, leading to differential erosion of the SFC Gravels (Figs. 4, 13b).

While the degradation of the Middle Pliocene SFC gravel sheet can be partly explained by a lowering of the erosional base level in response to subsidence of the Upper Rhine and Bresse Grabens (Ziegler and Dèzes 2007) it 
also coincided with the onset of thick-skinned tectonics throughout the RBTZ, associated with compressional to dextrally transpressional reactivation of various normal faults, possibly including the underlying Permo-Carboniferous Burgundy Trough System (Giamboni et al. 2004a; Ustaszewski and Schmid 2007; Madritsch et al. 2008). Hence, basement-rooted inversion tectonics presumably contributed to the differential post-Pliocene rock uplift of the RBTZ and related erosion of the SFC Gravels. This hypothesis is supported by morphologic observations along the Ognon Valley. The Ognon River shares the same base level as the Doubs River, namely the Saone River occupying the Bresse Graben (Fig. 4). Nevertheless, during the Late Pliocene and Pleistocene the Ognon drainage basin was characterised by only moderate river incision and ongoing sediment accumulation and subsidence whilst in the adjacent Doubs Valley the SFC gravel sheet was degraded (Fig. 13b). The asymmetric terrace distribution along the Ognon Valley is more likely due to thick-skinned inversion tectonics than to the propagation of the thinskinned thrust belt (Fig. 13b). Late-stage inversion of the Avant-Monts Fault, which underlies the décollement related Chailluz Anticline, is constrained by reflection-seismic data (Madritsch et al. 2008), whilst Pleistocene inversion of the Ognon Normal Fault is inferred from the incision of the Ognon River (Figs. 7, 8). Regional tilting caused by reverse faulting along the thick-skinned Avant-Mont Fault could also explain the apparently diverging migration of the Ognon and Doubs to the north and south, respectively (Fig. 13b), a feature that is difficult to explain by invoking ongoing thin-skinned fold and thrust belt propagation.

Deformation within the Besançon Zone continued beyond $2.9 \mathrm{Ma}$ as documented by remnants of Middle Pliocene SFC Gravels that are involved in folding at several locations along the Doubs Valley (Fig. 12). These observations contrast with the northwestern front of the Jura Mountains where such late-stage deformation was only recorded outside the fold-and-thrust belt proper (Nivière and Winter 2000; Giamboni et al. 2004a). In the study area, reconstruction of the river incision and deformation history reveals that along the Doubs Valley, folding occurred simultaneously with focused Pleistocene river incision (Dreyfuss and Glangeaud 1950; Madritsch 2008). Under such spatial and temporal conditions river incision can theoretically modulate, and eventually enhance deformation according to recent mathematical coupled deformation-surface process models (Simpson 2004; Zeilinger et al. 2005). Thereby, syn-kinematic erosional breaching of the elastic beam controlling the geometry of an evolving thin-skinned flexural-slip fold causes strain concentration that typically leads to the development of doubly plunging anticlines, such as the Clerval and Citadelle Anticline. Hence, the probable positive feedback between folding and river incision throughout the Besançon Zone would imply that Pleistocene shortening of the Mesozoic cover sequence is, at least locally, still decoupled from the basement and that ongoing décollement related deformation in this part of the fold-and-thrust belt cannot be excluded (Fig. 13c).

In principle, the apparent back-stepping of the active fold-and-thrust belt front (Fig. 13c) could be interpreted in terms of the critically tapered wedge theory and the related cyclic evolution of fold-and-thrust belt wedges (Davis et al. 1983; DeCelles and Mitra 1995). Regional Plio-Pleistocene uplift and erosion may have transferred the critically tapered wedge of the thin-skinned Jura fold-and-thrust belt that had stalled around the Early Pliocene into a sub-critical stage, initiating renewed out-of-sequence deformation within the fold-and-thrust belt. Analogue models support such a hypothesis (Smit et al. 2002). However, the seismicity of the region (Baer et al. 2005, 2007) implies that at present deformation in the RBTZ area is thick-skinned and also involves the underlying basement (Figs. 2, 3). The critically tapered wedge theory s. str. is, therefore, not applicable unless one also considers the basement as being part of the deforming wedge (Lacombe and Mouthereau 1999; Mosar 1999). The active shortening of the cover sequence is more likely caused by basement fault reactivation in the Molasse basin or the Rhine-Bresse Transfer Zone itself (Pfiffner et al. 1997; Mosar 1999; Ustaszewski and Schmid 2007; Roure 2008; Madritsch et al. 2008) rather than being rooted in the Central Alps as was the case during Late Miocene-Early Pliocene formation of the thinskinned Jura fold-and-thrust belt (e.g. "distant push"; Laubscher 1961).

\section{Conclusion}

Paleo-topographic reconstruction of the Middle Pliocene Sundgau-Forêt de Chaux Gravels indicates regional Late Pliocene and Pleistocene relative uplift of the northwestern front of the Jura Mountains. The uplifted area includes the most external segment of the Jura fold-and-thrust belt and its foreland comprising the intra-continental Rhine-Bresse Transfer Zone.

Relative uplift of this area, amounting to a maximum of $170 \mathrm{~m}$ (Deluz) translates into a minimum uplift rate of $0.05 \pm 0.02 \mathrm{~mm} /$ year. This is in good agreement with the results of geomorphic studies in adjacent areas. The Plio-Pleistocene evolution of the Ognon and Doubs River drainage basins indicates that their uplift relative to the Upper Rhine and Bresse grabens was at least partly driven by tectonic contraction post-dating the main deformation phase of the thin-skinned Jura fold-andthrust belt. 
Two different types of post-Pliocene deformation were identified. First, the basement-involving thick-skinned deformation that resulted in partial compressional to transpressional inversion of the Rhine-Bresse Transfer Zone, and which is apparently still active as indicated by the seismicity of the region. Second, there are geomorphic indications for locally still active folding that is related to, and possibly influenced by focused Pleistocene river incision occurring in response to regional rock uplift. The apparent positive feedback between folding and Pleistocene incision suggests that the Mesozoic cover sequence still undergoes active shortening in response to regional horizontal compression, with deformation being decoupled from the immediately underlying basement. Hence, these observations suggest Pleistocene deformation along the same décollement horizon that was active during the Late Miocene-Early Pliocene development of the thin-skinned Jura fold-and-thrust belt. As a consequence, apparently a-seismic shallow folding and thrusting is locally superimposed on seismogenic inversion tectonics rooted in the basement.

Our results show a variety of positive feedback mechanisms between deformation-related uplift and erosion during the Plio-Pleistocene evolution of the Jura fold-andthrust belt and its foreland. Uplift and erosion, at least partly in response to basement-involved inversion tectonics, was apparently accompanied by localised resumption of active folding within the Jura fold-and-thrust belt.

Acknowledgments This project was carried out in the framework of the EUCOR-URGENT project whereby the first author was funded by ELTEM (Universität Basel) and the "Freiwillige Akademische Gesellschaft Basel". We would like to thank all our colleagues of the EUCOR URGENT team at the Geological Institute Basel. Special thanks are extended to V. Bichet, M. Campy, B. Regent, F. Schlunegger, M. Schnellmann, T. Vietor and A. Wetzel for sharing their experience during joint field trips and discussions. Constructive comments by A. Sommaruga and an anonymous reviewer significantly improved the original manuscript.

\section{References}

Baer M, Deichmann N, Braunmiller J et al (2005) Earthquakes in Switzerland and surrounding regions during 2004. Eclogae Geol Helv 98:407-418. doi:10.1007/s00015-005-1168-3

Baer M, Deichmann N, Braunmiller J et al (2007) Earthquakes in Switzerland and surrounding regions during 2006. Swiss J Geosci 100:517-528. doi:10.1007/s00015-007-1242-0

Becker A (2000) The Jura Mountains-an active foreland fold-andthrust belt? Tectonophysics 321:381-406. doi:10.1016/S00401951(00)00089-5

Berger JP, Reichenbacher B, Becker D et al (2005) Paleogeography of the Upper Rhine Graben (URG) and the Swiss Molasse Basin (SMB) from Eocene to Pliocene. Int J Earth Sci 94:697-710. doi: 10.1007/s00531-005-0475-2

Boenigk W (1982) Der Einfluss des Rheingraben-Systems auf die Flussgeschichte des Rheins. Z Geomorph N F 42:167-175

Boenigk W (1983) Schwermineralanalyse. Enke, Stuttgart
Boenigk W (1987) Petrographische Untersuchungen juntertiärer und quartärer Sediments am linken Oberrhein. Jber u Mitt oberrh geol Ver 69:357-394

Boigk H, Schönreich H (1970) Die Tiefenlage der Permbasis im nördlichen Teil des Oberrheingrabens. In: Illies JH, Mueller S (eds) Graben problems. Proceedings of an International Rift Symposium held in Karlsruhe 1968, International Upper Mantle Project. E Schweitzerbart'sche, Stuttgart, pp 45-55

Bonvalot J (1974) Les cailloutis de la Forêt de Chaux (Jura): leurs rapports avec les matériaux détritiques de Sundgau et du Nord de la Bresse. Université de Dijon, Dijon

Bull WB (1990) Stream-terrace genesis: implications for soil development. Geomorphology 3:351-367. doi:10.1016/0169555X(90)90011-E

Bull WB, McFadden LD (1977) Tectonic geomorphology north and south of Garlock fault, California. In: Doehring DO (ed) Geomorphology in arid regions. Proceedings of the 8th Annual Geomorphology Symposium. Universtiy of New York, Binghampton, pp 115-138

Burkhard M (1990) Aspects of the large-scale Miocene deformation in the most external part of the Swiss Alps (Subalpine Molasse to Jura fold belt). Eclogae Geol Helv 83(3):559-583

Burkhard M, Sommaruga A (1998) Evolution of the western Swiss Molasse basin: structural relations with the Alps and the Jura belt. In: Mascle A, Puidgefàbregas C, Luterbacher HP et al (eds) Cenozoic foreland basins of western Europe, Geological Society, London, Special Publications 134: 279-298

Campy M (1984) Signification dynamique et climatique des formations et terrasses fluviatiles dans un environnement de moyenne montagne. Bulletin de l'Association française pour l'Etude du Quaternaire 1:87-92

Campy M, Contini D (1981) La néotectonique en Franche-Comté (France), Vosges méridionales-Jura septentrional. Bulletin de 1'Association française pour 1'Etude du Quaternaire 3-4: 193-205

Cederbom CE, Sinclair HD, Schlunegger F et al (2004) Climateinduced rebound and exhumation of the European Alps. Geology 32(8):709-712. doi:10.1130/G20491.1

Chauve P, Campy M, Kerrien Y et al (1979) Carte géolog. France (1/50000), feuille Dole XXXII-24. BRGM, Orléans

Chauve P, Enay R, Fluck P et al (1980) L'Est de la France (Vosges, Fossé Rhénan, Bresse, Jura). Annales scientifiques de l'Université de Besançon 4(1):3-80

Chauve P, Campy M, Pernin C et al (1983) Carte géolog. France (1/50000), feuille Pesmes, XXXII-23. BRGM, Orléans

Contini D, Théobald N (1974) Relations entre le fossé rhenan et le fossé de la Saône. Tectonique des régions sous-vosgiennes et pré-jurassiennes. In: Illies $\mathrm{JH}$, Fuchs $\mathrm{K}$ (eds) Approaches to taphrogenesis. Sc Report, Stuttgart, pp 310-321

Contini D, Kuntz G, Angély B et al (1973) Carte géolog. France (1/50000), feuille Montbéliard, XXXV-22. BRGM, Orléans

Coromina G, Fabbri O (2004) Late Palaeozoic NE-SW ductile-brittle extension in the La Serre horst, eastern France. C R Geosci 336(1):75-84. doi:10.1016/j.crte.2003.09.019

Davis D, Suppe J, Dahlen FA (1983) Mechanics of fold-and-thrustbelts and accretionary wedges. J Geophys Res 88:1153-1172. doi:10.1029/JB088iB02p01153

Debrand-Passard S, Courbouleix S (1984) Synthèse géologique du sud-est de la France, volume 2: atlas comprenant 64 planches en couleurs. Mémoire du Bureau de recherches géologiques et minières, 126. BRGM, Orléans, p 614

DeCelles PG, Mitra G (1995) History of the Sevier orogenic wedge in terms of critical taper models, northeast Utah and southwest Wyoming. Geol Soc Am Bull 107(4):454-462. doi:10.1130/ 0016-7606(1995) 107<0454:HOTSOW >2.3.CO;2

Dèzes P, Schmid SM, Ziegler PA (2004) Evolution of the European Cenozoic Rift System: interaction of the Alpine and Pyrenean 
orogens with their foreland lithosphere. Tectonophysics 389(1-2):1-33. doi:10.1016/j.tecto.2004.06.011

Dreyfuss M, Glangeaud L (1950) La vallée du Doubs et l'évolution morphotectonique de la région bisontine. Annales scientifiques de l'Université de Besançon 5:2

Dreyfuss M, Kuntz G (1969) Carte géolog. France (1/50000), feuille Besançon, XXXII-23. BRGM, Orléans

Dreyfuss M, Kuntz G (1970) Carte géolog. France (1/50000), feuille Gy, XXXIII-22. BRGM, Orléans

Dreyfuss M, Théobald N (1972) Carte géolog. France (1/50000), feuille Baume-les-Dames, XXXIV-22. BRGM, Orléans

Fejfar O, Heinrich WD, Lindsay EH (1998) Updating the Neogene rodent biochronology in Europe. Mededelingen Ned Instituut Toegepaste Geowetenschappen TNO 60:533-554

Giamboni M, Ustaszewski K, Schmid SM et al (2004a) PlioPleistocene Transpressional Reactivation of Paleozoic and Paleogene Structures in the Rhine-Bresse transform Zone (northern Switzerland and eastern France). Int J Earth Sci 93(2):207-223. doi:10.1007/s00531-003-0375-2

Giamboni M, Wetzel A, Niviere B et al (2004b) Plio-Pleistocene folding in the southern Rhinegraben recorded by the evolution of the drainage network (Sundgau area: northwestern Switzerland and France). Eclogae Geol Helv 97:17-31. doi:10.1007/s00015004-1112-4

Goguel J, Dreyfuss M (1965) Carte géolog. France (1/50000), feuille Vercel, XXXIV-23. BRGM, Orléans

Hagedorn EM (2004) Sedimentpetrographie und Lithofazies der jungtertiären und quartären Sedimente im Oberrheingebiet. University of Cologne, Cologne, p 310

Hagedorn EM, Boenigk W (2008) The Pliocene and Quaternary sedimentary and fluvial history in the Upper Rhine Graben based on heavy mineral analyses. Neth J Geosci 87(1):21-31

Hinsken S, Ustaszewski K, Wetzel A (2007) Graben width controlling syn-rift sedimentation: the Palaeogene southern Upper Rhine Graben as an example. Int J Earth Sci 96(6):979-1002. doi: 10.1007/s00531-006-0162-y

Holbrook J, Schumm SA (1999) Geomorphic and sedimentary response of rivers to tectonic deformation: a brief review and critique of a tool for recognizing subtle epiorogenic deformation in modern and ancient settings. Tectonophysics 305:287-306. doi:10.1016/S0040-1951(99)00011-6

Illies JH (1972) The Rhinegraben rift system-plate tectonics and transform faulting. Geophys Surv 1:27-60. doi:10.1007/ BF01449550

Kälin D (1997) Litho- und Biostratigraphie der mittel- bis obermiozänen Bois de Raube-Formation (Nordwestschweiz). Eclogae Geol Helv 90(1):97-114

Kastrup U, Zoback ML, Deichmann N (2004) Stress field variations in the Swiss Alps and the northern Alpine foreland derived from inversion of fault plane solutions. J Geophys Res 109(B01402). doi:10.1029/2003JB002550 doi:10.1029/2003JB002550

Kuhlemann J, Frisch W, Szekely B et al (2002) Post-collisional sediment budget history of the Alps: tectonic versus climatic control. Int J Earth Sci 91:818-837. doi:10.1007/s00531-0020266-y

Lacombe O, Mouthereau F (1999) Qu'est-ce que le front des orogènes? L'exemple de l'orogène pyrénéen. CR Acad Sci Paris Science de la terre et des planètes 329:889-896

Lacombe O, Angelier J, Byrne D et al (1993) Eocene-Oligocene tectonics and kinematics of the Rhine-Saone continental transform zone (Eastern France). Tectonics 12(4):874-888. doi: 10.1029/93TC00233

Laubscher H (1961) Die Fernschubhypothese der Jurafaltung. Eclogae Geol Helv 54(1):222-282

Laubscher H (1970) Grundsätzliches zur Tektonik des Rheingrabens. In: Illies JH, Mueller S (eds) Graben Problems. Proceedings of an International Rift Symposium held in Karlsruhe 1968, International Upper Mantle Project, E. Schweitzerbart'sche, Stuttgart, pp 79-86

Laubscher H (1972) Some overall aspects of Jura dynamics. Am J Sci 272:293-304

Liniger H (1966) Das Plio-Altpleistozäne Flussnetz der Nordschweiz. Regio Basil 7:158-177

Liniger H (1967) Pliozän und Tektonik des Jura Gebirges. Eclogae Geol Helv 60(2):407-490

Liniger H, Hofmann P (1965) Das Alter der Sundgauschotter westlich von Basel. Eclogae Geol Helv 58(1):215-230

Madritsch H (2008) Structural evolution and neotectonics of the RhineBresse Transfer Zone. Ph.D. Thesis, University of Basel, p 178

Madritsch H, Schmid SM, Fabbri O (2008) Interactions between thinand thick-skinned tectonics at the northwestern front of the Jura fold-and-thrust-belt (Eastern France). Tectonics 27:TC5005. doi: 10.1029/2008/TC002282 doi:10.1029/2008TC002282

Madritsch H, Kounov A, Schmid SM et al (2009) Multiple fault reactivations within the intracontinental Rhine-Bresse Transfer Zone (La Serre Horst, Eastern France). Tectonophysics 471:297318. doi:10.1016/j.tecto.2009.02.044

Martin J, Mercier E (1996) Héritage distensif et structuration chevauchante dans une chaîne de couverture: apport de l'équilibrage par modélisation géométrique dans le Jura nordoccidental. Bull Soc Geol Fr 167(1):101-110

Mayer-Rosa D, Cadiot B (1979) Review of the 1356 Basel earthquake: basic data. Tectonophysics 53:325-333. doi: 10.1016/0040-1951(79)90077-5

Mercier JL, Jeser N (2004) The glacial history of the Vosges Mountains. In: Ehlers J, Gibbard PL (eds) Quaternary glaciations - extent and chronology. Part 1: Europe. Elsevier, Amsterdam, pp 113-118

Merritts DJ, Vincent KR, Wohl EE (1994) Long river profiles, tectonism and eustasy: a guide to interpreting fluvial terraces. J Geophys Res 99(B7):14031-14050. doi:10.1029/94JB00857

Meyer B, Lacassin R, Brulhet J et al (1994) The Basel 1356 earthquake: which fault produced it? Terra Nova 6:54-63. doi: 10.1111/j.1365-3121.1994.tb00633.x

Mosar J (1999) Present-day and future tectonic underplating in the western Swiss Alps: reconciliation of basement/wrench-faulting and décollement folding of the Jura and Molasse basin in the Alpine foreland. Earth Planet Sci Lett 173:143-155. doi: 10.1016/S0012-821X(99)00238-1

Müller WH, Naef H, Graf HR (2002) Geologische Entwicklung der Nordschweiz, Neotektonik und Langzeitszenarien, Zürcher Weinland. Nagra Technischer Bericht, 99-08. Nagra, Wettingen, p 226

Nivière B, Marquis G (2000) Evolution of terrace risers along the Upper Rhine Graben inferred from morphologic dating methods: evidence of climatic and tectonic forcing. Geophys $\mathrm{J}$ Int 141(3):577-594. doi:10.1046/j.1365-246x.2000.00123.x

Nivière B, Winter T (2000) Pleistocene northwards fold propagation of the Jura within the southern Upper Rhine Graben: seismotectonic implications. Glob Planet Change 27:263-288. doi: 10.1016/S0921-8181(01)00070-4

Ouchi S (1985) Response of alluvial rivers to slow active tectonic movement. Geol Soc Am Bull 96(4):504-515. doi:10.1130/ 0016-7606(1985)96<504:ROARTS $>2.0 . C O ; 2$

Peters G, van Balen RT (2007) Tectonic geomorphology of the northern Upper Rhine Graben, Germany. Glob Planet Change 58:310-334. doi:10.1016/j.gloplacha.2006.11.041

Petit C, Campy M, Chaline J et al (1996) Major palaeohydrographic changes in Alpine foreland during the Pliocene-Pleistocene. Boreas 25:131-143

Pfiffner OA, Erard P, Stäuble M (1997) Two cross sections through the Swiss Molasse Basin (lines E4-E6, W1, W7-W10). In: 
Pfiffner OA, Lehner P, Heitzmann P et al (eds) Deep structure of the Swiss Alps. Results of NRP 20. Birkhäuser, pp 64-72

Reinecker J, Heidbach O, Tingay B et al (2005) The 2005 release of the World Stress Map. Available via www.world-stress-map.org

RéNaSS (2007) Réseau National de Surveillance Sismique. Available via http://renass.u-strasbg.fr/

Rotstein Y, Schaming M (2004) Seismic reflection evidence for thickskinned tectonics in the northern Jura. Terra Nova 16:250-256. doi:10.1111/j.1365-3121.2004.00560.x

Roure F (2008) Foreland and Hinterland basins: what controls their evolution? Swiss J Geosci 101(Suppl 1):S5-S29. doi:10.1007/ s00015-008-1285-x

Ruhland M (1959) Une dislocation majeure du socle Vosgien dans la haute Vallée de l'Ognon. Bull Serv Carte Geol Als Lorr 12:61-64

Schmid SM, Pfiffner OA, Froitzheim N et al (1996) Geophysicalgeological transect and tectonic evolution of the Swiss-Italian Alps. Tectonics 15:1036-1064. doi:10.1029/96TC00433

Simpson G (2004) Role of river incision in enhancing deformation. Geology 32(4):341-344. doi:10.1130/G20190.2

Sindowski KH (1949) Results and problems of heavy mineral analysis in Germany; a review of sedimentary-petrological papers 19361948. J Sediment Petrol 19:3-25

Sissingh W (1998) Comparative Tertiary stratigraphy of the Rhine Graben, Bresse Graben and Molasse Basin: correlation of Alpine foreland events. Tectonophysics 300:249-284. doi:10.1016/ S0040-1951(98)00243-1

Smit JHW, Brun JP, Sokoutis D (2002) Deformation of brittle-ductile thrust wedges in experiments and nature. Journal of Geophysical Research 108 B10 2480. doi:10.1029/2002JB002190

Sommaruga A (1997) Geology of the Central Jura and the Molasse Basin: new insights into an evaporite-based foreland fold and thrust belt. Schweizerische Akademie der Naturwissenschaften, Neuchatel, p 176

Tesauro M, Hollenstein C, Egli R et al (2005) Continuous GPS and broad-scale deformation across the Rhine Graben and the Alps. Int J Earth Sci 94:525-537. doi:10.1007/s00531-004-0453-0
Théobald N, Schweitzer M, Hudeley H (1976) Carte Géologique de la France à 1/50 000 Mulhouse, feuille XXXVII-XXXVIII-20. Ministère de l'industrie et de la recherche, Service Géologique National, Orléans

Théobald N, Vogt H, Wittmann O (1977) Néotectonique de la partie méridionale du bloc rhénan. Bull BRGM 2(4):121-140

Thiébaut J, Théobald N, Hudeley H (1974) Carte géolog. France (1/50000), feuille Giromagny, XXXV-22. BRGM, Orléans

Ustaszewski K, Schmid SM (2006) Control of preexisting faults on geometry and kinematics in the northernmost part of the Jura fold-and-thrust belt. Tectonics 25:TC5003. doi:10.1029/2005 TC001915

Ustaszewski K, Schmid SM (2007) Latest Pliocene to recent thickskinned tectonics at the Upper Rhine Graben-Jura Mountains junction. Swiss J Geosci 100(2):293-312. doi:10.1007/s00015007-1226-0

Van Andel TH (1950) Provenance, transport and deposition of Rhine sediments. Veenman \& Zonen, Wageningen, p 129

Zeilinger G, Schlunegger F, Simpson G (2005) The Oxaya anticline (northern Chile): a buckle enhanced by river incision? Terra Nova 17:368-375. doi:10.1111/j.1365-3121.2005.00622.x

Ziegler PA (1990) Geological Atlas of Western and Central Europe, Shell Internationale Petroleum Maatschappij BV. Geological Society Publishing House Bath, Den Haag, pp 1-238

Ziegler PA (1992) European Cenozoic rift system. Tectonophysics 208:91-111. doi:10.1016/0040-1951(92)90338-7

Ziegler PA, Dèzes P (2007) Cenozoic uplift of Variscan Massifs in the foreland of the Alpine foreland: timing and controlling mechanisms. Glob Planet Change 58:237-269. doi:10.1016/ j.gloplacha.2006.12.004

Ziegler PA, Fraefel M (2009) Response of drainage systems to Neogene evolution of Jura fold-thrust belt and Upper rhine Graben. Swiss J Earth Sci 102(1):57-75 